\title{
Taxing capital and labor when both factors are imperfectly mobile internationally
}

\author{
Hippolyte d'Albis ${ }^{1}$ D $\cdot$ Agnès Bénassy-Quéré
}

Accepted: 13 February 2021 / Published online: 25 March 2021

(C) The Author(s), under exclusive licence to Springer Science+Business Media, LLC, part of Springer Nature 2021

\begin{abstract}
We revisit the standard theoretical model of tax competition to consider imperfect mobility of both capital and labor. We show that the mobility of one factor affects the taxation of both factors and that the "race-to-the-bottom" narrative (with burden shifting) applies essentially to capital-exporting countries. We validate our predictions using a panel of 29 OECD countries over the period of 1997-2017. The quantitative contribution of rising capital mobility to the decline of corporate income tax rates over our sample period is nonetheless less than that of population ageing.
\end{abstract}

Keywords Tax competition · Globalization · Imperfect factor mobility

JEL Classification F21 $\cdot$ F22 $\cdot$ H25

\section{Introduction}

The rich theoretical literature on tax competition ${ }^{1}$ generally finds that, when capital is mobile and other production factors are immobile, it is optimal for a benevolent government to finance the provision of public goods by taxing immobile bases only and therefore not to tax capital (see Zodrow \& Mieszkowski, 1986; Wildasin, 1988; Wilson, 1999). ${ }^{2}$ Tax competition is especially fierce at source, as seen with

\footnotetext{
1 See, e.g., Keen and Konrad (2013).

2 Mendoza and Tesar (2005) show, within a general equilibrium framework, that capital mobility may not trigger a "race-to-the-bottom" in capital taxation on account of inefficiency costs associated with the taxation of labor.
}

Hippolyte d'Albis

hdalbis@psemail.eu

Agnès Bénassy-Quéré

agnes.benassy@univ-paris1.fr

1 Paris School of Economics, CNRS, 48 Boulevard Jourdan, 75014 Paris, France

2 Paris School of Economics, University Paris 1 Panthéon-Sorbonne, Paris, France 
corporate income tax rates, with both statutory and effective corporate tax rates having decreased in general across advanced economies since the mid-1990s. ${ }^{3}$

The empirical literature has remained strikingly inconclusive about the impact of international capital mobility on corporate income tax (see the meta analysis of Adam et al. (2013)). The surprising lack of a clear empirical conclusion may be explained in different ways. First, financial globalization has been closely related to population ageing: whatever a country's level of openness, an ageing median voter may favor lower capital taxation. ${ }^{4}$ Second, the opening up of the economy makes households more vulnerable to external (terms of trade) shocks; they ask (and get) insurance from the government, which increases the size of the government, resulting in higher taxation (Rodrik, 1998). Third, financial integration has often come together with increased social and political integration, resulting in forces with opposing effects on capital taxation (Dreher, 2006). Finally, financial globalization, like the opening up of trade, is a common feature of advanced economies throughout the 1990s and 2000s. As evidenced by, for example, Slemrod (2004), this makes it difficult to identify its impact once time fixed effects are introduced.

In this paper, we propose an alternative explanation for the apparently limited effect of financial globalization on capital taxation, by removing the extreme assumption of perfect capital mobility. In a world of imperfect capital mobility, a capital-importing country (whose productive capital is partly held by nonresidents) needs to offer a higher after-tax return than the rest of the world, hence a lower tax rate, in order to attract foreign capital. Conversely, a capital-exporting country (whose private wealth is partly invested overseas) may enjoy a higher tax rate than the rest of the world. With financial globalization, differentials in after-tax returns diminish: the capital-importing country may raise its tax rate, whereas the net capital exporter has to reduce its own tax rate. As such, the "race-to-the-bottom" story should only apply to capital-exporting countries, being those with a negative net foreign direct investment position. We validate this prediction with panel data estimations for 29 OECD countries over the period of 1997-2017, after controlling for population ageing, fixed effects, and rising labor mobility.

Imperfect capital mobility has been widely documented in the literature, such as with the significant and persistent home bias in international portfolio choices. ${ }^{5}$ At the macroeconomic level, imperfect capital mobility translates into a wedge between after-tax returns across countries, depending on whether each country is a net capital exporter or importer. Horioka and Ford (2017) explain why return differentials are not eliminated within increased financial integration. However, the literature on tax competition generally considers capital to be perfectly mobile, which leads to an equalization of after-tax returns. An exception is Lee (1997), who introduces

\footnotetext{
3 Residence-based capital taxes have also decreased, but the literature on tax competition mostly focuses on the corporate income tax, which does not involve any mobility of the taxpayer (only a mobility of the tax base).

4 Adam and Kammas (2007) find a significant, negative impact of the share of the population over 65 on corporate income tax rates. In general, though, the empirical literature does not control for population ageing.

5 See the seminal paper by French and Poterba (1991), or the literature review by Lewis (1999).
} 
transaction costs within a model with two jurisdictions. In this setting, tax competition may lead to higher capital tax rates because each jurisdiction disregards the fact that raising its own tax depresses the after-tax return in both jurisdictions. Yet, transaction costs are given here, whereas in the macroeconomic literature, an indebted country will need to offer a higher after-tax return than the rest of the world if it wants to keep its foreign capital.

Conversely, the literature on tax competition considers labor to be immobile, which is inconsistent with increased international mobility of labor over the past three decades, especially within the European Union where legal barriers to labor mobility have been eliminated. From 1997 to 2017, according to our data (see Sect. 4), labor mobility among OECD countries increased by more than twofold on average, while capital mobility increased by more than threefold. Rising labor mobility may mitigate the "burden-shifting," or "compensation effect" (Adam \& Kammas, 2007), of financial globalization in three ways. First, it may put downward pressure on the taxation of labor, particularly at relatively high levels of compensation. ${ }^{6} \mathrm{Sec}-$ ond, to the extent that mobile workers are in a position to take decisions concerning the location of capital (both at the firm level and as savers), labor and capital mobility are likely to be intertwined. Third, labor and capital mobility interact with each other since the marginal productivity of one factor depends on the quantity of the other factor (see Wilson, 1995). In Bucovetsky and Wilson (1991), Razin and Sadka (1991), labor supply is endogenous, which weakens the standard result of taxation falling on the immobile base. However, these authors do not consider labor mobility across jurisdictions. Bucovetsky (2003), Razin and Sadka (2012) do consider labor mobility, but they assume a degree of heterogeneity between local and immigrant workers in terms of their productivity or capital endowment.

We consider a model of tax competition à la Zodrow and Mieszkowski (1986), where the benevolent government of a small open economy maximizes the average household's utility, which itself depends on the consumption of both a private good and of a public good. The public good is financed through two taxes at source: one on capital (i.e. a corporate income tax) and the other on labor. Both capital and labor are imperfectly mobile internationally. However, we assume an asymmetry between capital and labor: while workers must be residents of the same country in which they work, capital owners may be residents or nonresidents. ${ }^{7}$ Our model also features pensioners who only receive capital income on top of a fixed pension.

\footnotetext{
${ }^{6}$ For instance, Liebig et al. (2007), Kleven et al. (2013) and Kleven et al. (2014) find very high elasticities for top-income foreign workers to tax differentials. Since foreign workers are a relatively small proportion of the high-income population, Piketty and Saez (2012), Lehmann et al. (2014) retain an elasticity of 0.25 for top-income earners. Lehmann et al. (2014) show that, if the semi-elasticity of migration increases for higher incomes, then it is optimal to reduce the marginal tax rates on top-income earners.

7 This assumption, occasionally described as a "regional model," is standard in the literature, especially for international tax competition (see Wilson, 1999). The literature on local tax competition, however, has often studied "metropolitan" models, where individuals commute between their home and their work (see Braid, 1996). In Richter and Wellisch (1996), households work in their country of residence while holding capital in other jurisdictions. However, they have a fixed supply of their capital (land) in each jurisdiction.
} 
We first show that capital and labor taxation generally coexist, which contrasts with the standard competition model where the mobile factor is not taxed. We then study the impact of factor mobility on both tax rates, through a full derivation of a simplified model and through simulations of the general model. We find that the government will reduce the tax rate on capital as a result of increased capital mobility (a "race-to-the-bottom" narrative) and increase the tax rate on labor (burden-shifting), but mostly if the country is a capital-exporting country. For a capitalimporting country, the impact of financial integration on changes in tax rates is very limited. Furthermore, we show that though the international position of a country on the labor market ought to be considered together with its position on the capital market, our findings produce no general result.

We therefore show that, in a world of imperfect capital mobility, the race-to-thebottom of capital taxation only applies to capital-exporting countries, hence countries with high capital endowments. ${ }^{8}$ This result is robust to the introduction of labor mobility, regardless of a country's labor endowment. We also show that taxation levels are more sensitive to population ageing in capital-exporting nations than in those who are net capital importers.

We validate our theoretical predictions on a panel of 29 OECD countries over the period of 1997-2017. We study the impact of factor mobility on the Effective Average Tax Rate (EATR) and on the tax wedge on relatively high wages (where gross income represents $167 \%$ of average earnings), while paying close attention to a number of other variables that may also have impacted tax rates over our sample period: trade openness, population ageing, government spending, and government debt. We also control for country and time fixed effects, and we interact factor mobility with proxies for whether a country is a net factor-importer or exporter. We find evidence that capital mobility has a negative impact on capital taxation and a positive impact on labor taxation, a result that holds only for capital-exporting countries. Conversely, labor mobility has positive impact on capital taxation but no significant effect on labor taxation. The quantitative contribution of rising capital mobility to the decline of capital tax rates over our sample period is nonetheless less than that of population ageing. Our results are robust to a series of robustness checks.

We conclude that the mixed results found in the literature concerning the relationship between international capital mobility and capital taxation can be improved by relaxing the extreme assumptions of full capital mobility and full labor immobility, properly controlling for other relevant variables, accounting for population ageing, and by differentiating countries according to their net investment position.

The remainder of the paper is organized as follows. Section 2 outlines our theoretical setting and analytically solves a simplified version of the model. Section 3 presents the calibration and simulation of the complete model. In Sect. 4, we introduce our empirical strategy and describe the data used. The econometric results are

\footnotetext{
${ }^{8}$ Peralta and van Ypersele (1991) also highlight the importance of capital endowments in a two-country framework where labor is not mobile.
} 
presented in Sect. 5 before Sect. 6 describes four robustness exercises. Section 7 concludes.

\section{Theory}

We consider a small open economy where production is achieved using two internationally mobile factors-capital and labor. A public good is financed through the taxation of capital and labor at source. The government chooses the optimal taxes on these production factors in order to maximize a utility function that depends on public spending and on the after-tax national income per inhabitant. The novelty of this model à la Zodrow and Mieszkowski (1986) is to allow for imperfect mobility of both factors and to highlight the cross effects of the mobility of one factor on the taxation of the other factor. Our setting allows us to explore the impact of factor mobility on taxation depending on whether the economy is a net exporter or importer of capital, which in turn depends on the exogenous factor endowments of the economy. An additional innovation of this approach is the incorporation of pensioners who only receive capital income on top of their fixed pensions.

\subsection{Production and incomes}

Production is achieved using two internationally mobile factors, capital and labor, denoted $K$ and $L$, respectively. The production function is written as $F(K, h L)$, where $F($., .) satisfies constant returns-to-scale, is increasing and concave in each argument and satisfies Inada conditions and where $h>0$ is an exogenous scaling parameter that represents labor productivity. We assume that capital and labor are taxed at source at rates $\tau_{K}$ and $\tau_{L}$, respectively. We denote by $r^{*}$ and $w^{*}$ the international aftertax return of capital and labor, respectively, and by $r$ and $w$ the domestic after-tax return of each factor such that:

$$
r:=F_{K}^{\prime}(., .)-\tau_{K} \text { and } w:=F_{L}^{\prime}(., .)-\tau_{L} .
$$

We assume there are two types of agents living in this economy: (mobile) workers, assumed to be equal to the labor force $L$, and (immobile) pensioners of mass $D .{ }^{9}$ Both workers and pensioners have the same, exogenous capital endowment, denoted $\bar{k}^{10}$ and thus the total capital endowment in the economy depends on the number of residents: $\bar{K}=(L+D) \bar{k}$. Similarly, we have $K=(L+D) k$, where $k$ denotes the endogenous stock of productive capital per resident.

Both workers (who are supposed to live in the same country where they work) and pensioners can invest their capital endowment in a different country. Capital

\footnotetext{
9 The importance of including pensioners in the model will become clear in the econometric section of the paper. The assumption that they are immobile is made for computational convenience. Although in reality pensioners are partly mobile, assuming that they are immobile allows us to capture the existence of immobile capital holders in the economy.

10 Our study does not explore the results arising from heterogeneous capital levels between natives and migrants (Razin \& Sadka, 2012) nor from heterogeneous productivity levels (Bucovetsky, 2003).
} 
income is the sum of the domestic capital income $r k$ and of the revenue of the net investment position, given by $\bar{k}-k$. Importantly, a positive net investment position (i.e. when the country is a net exporter of capital: $\bar{k} \geq k$ ) yields the foreign after$\operatorname{tax}$ return $r^{*}$, whereas a negative net investment position (net importer of capital: $\bar{k} \leq k$ ) costs the domestic after-tax return $r$, as part of the domestic capital income is channeled to foreign investors. The remaining earnings are made up of an (aftertax) wage $w$ for workers, and of an exogenous pension, denoted by $p$, for pensioners. Hence, the private (or disposable) income of each worker and pensioner, denoted by $y_{L}$ and $y_{D}$, respectively, is given by: ${ }^{11}$

$$
y_{L}=\mid \begin{aligned}
& r k+r^{*}(\bar{k}-k)+w \text { if } \bar{k} \geq k \\
& r \bar{k}+w \text { if } \bar{k} \leq k
\end{aligned}
$$

and

$$
y_{D}=\mid \begin{aligned}
& r k+r^{*}(\bar{k}-k)+p \text { if } \bar{k} \geq k, \\
& r \bar{k}+p \text { if } \bar{k} \leq k
\end{aligned}
$$

Of note in our model is the fact that workers may either relocate internationally with their capital endowment or stay home and invest their endowment overseas. There is therefore an asymmetry between capital and labor: attracting a new worker will automatically attract a new capital endowment, whereas attracting new capital will attract new workers only through the induced rise in the marginal productivity of labor. ${ }^{12}$ We now turn to the conditions that provide the wedge between the domestic and the international returns of both factors.

\subsection{No-arbitrage conditions with imperfect factor mobility}

Unlike the existing literature on tax competition, we assume that both capital and labor are imperfectly mobile and that the extent of mobility may differ for capital and labor. In macroeconomic models, frictions in the international capital market are typically formalized as departures from uncovered interest rate parity, conditional on the net foreign asset position of the country, with these departures relying on utility maximization by the representative household or financial intermediary

\footnotetext{
11 If $\bar{k}=k$, then the alternative expressions of $y_{L}$ and $y_{D}$ are equivalent since $r=r^{*}$, see the next subsection.

12 Such asymmetry could be eliminated if workers were allowed to work and live in two different countries. Existing models of international tax competition generally disregard this possibility. According to Eurostat, cross-border commuters represented less than 1 percent of the workforce in the European Union in 2018. The development of cross-border telecommuting and more generally of telepresence may raise this proportion in the future (see Baldwin, 2016). Similarly, the location of home, capital and work may be blurred by tax avoidance. Tax avoidance can have similar impact as "true" mobility on tax rates (Fossen et al., 2020; Keen \& Konrad, 2013). It may also interact with "true" mobility. We leave this complication for future research.
} 
(see e.g. Itskhoki \& Mukhin, 2019; Lindé \& Pescatori, 2012). Although we do not formally study the behaviors of individuals, we consistently assume that the stock of productive capital in the domestic economy depends on the domestic endowment and on the gap between the domestic after-tax return on capital and the international remuneration of capital, which influences the international allocation of capital endowments: ${ }^{13}$

$$
K=\left[\bar{k}+\phi_{K}\left(r-r^{*}\right)\right](L+D),
$$

where $\phi_{K} \geq 0$ represents the degree of capital mobility. Hence, a country can enjoy productive capital in excess of its domestic endowment (i.e. $K>(L+D) \bar{k}$ ) if its after-tax return $r$ is greater than the international return $r^{*} .{ }^{14}$ In the limit case such that $\phi_{K}=0$, capital is immobile and we have $K=(L+D) \bar{k}$. Conversely, when $\phi_{K} \rightarrow \infty$, an infinitely small excess return is required to attract foreign capital, so at equilibrium the domestic after-tax return is equal to the international return: $r=r^{*}$. For intermediate values of $\phi_{K}$, the domestic after-tax return satisfies:

$$
r=r^{*}+\frac{k-\bar{k}}{\phi_{K}} .
$$

The literature on international migration has also formalized the remuneration wedge between host and origin countries as a function of market frictions (in this case, migration costs, see Borjas (1989)). By analogy with capital, we assume that the quantity of labor in the domestic economy depends on an exogenous labor endowment, denoted $\bar{L}$, and on the gap between the after-tax labor return and the international remuneration of labor:

$$
L=\bar{L}+\phi_{L}\left(w-w^{*}\right) L,
$$

where $\phi_{L} \geq 0$ represents the international mobility of labor. As for capital mobility, this parameter is scaled by the size of the economy, here $L$. For $\phi_{L}=0$, we have $L=\bar{L}$, while $\phi_{L} \rightarrow \infty$ corresponds to perfect labor mobility that implies $w=w^{*}$. For intermediate values of $\phi_{L}$, there is a wedge between the domestic after-tax wage and its international remuneration:

$$
w=w^{*}+\frac{1-\frac{\bar{L}}{L}}{\phi_{L}} .
$$

For given $K$ and $L$, the absolute size of the wedge in conditions (5) and (7) declines with higher factor mobility. For instance, higher capital mobility makes it easier for a net capital importer to attract foreign capital: the premium needed to attract

\footnotetext{
13 For simplicity, we consider the depreciation rate of capital to be equal to its price variation over one period, so that the user cost of capital is equal to its gross marginal return.

14 Symmetrically, $K<(L+D) \bar{k}$ is consistent with $r<r^{*}$.
} 
foreign investors is reduced, and the capacity to tax is increased. By replacing $r$ by $F_{K}^{\prime}(.,)-.\tau_{K}$ in $(5)$, we indeed get:

$$
\left.\frac{\partial \tau_{K}}{\partial \phi_{K}}\right|_{K, L \text { given }}=\frac{k-\bar{k}}{\phi_{K}^{2}} .
$$

For a given level of capital and labor, partial derivative (8) suggests that the tax rate on capital should increase with capital mobility for a net capital importer $(k>\bar{k})$ and decrease for a net capital exporter $(k<\bar{k})$. The same reasoning applies to labor, except that it is the difference between $L$ and $\bar{L}$ that is relevant. However, capital and labor will adjust to a change in factor mobility, so the model needs to be solved before it is possible to come to a conclusion.

By replacing the no-arbitrage conditions (5) and (7) in the equations that define private incomes, i.e. (2) and (3), we obtain:

$$
y_{L}=\mid \begin{aligned}
& w^{*}+\frac{\left(1-\frac{\bar{L}}{L}\right)}{\phi_{L}}+r^{*} \bar{k}+\left(\frac{k-\bar{k}}{\phi_{K}}\right) k \text { if } \bar{k} \geq k, \\
& w^{*}+\frac{\left(1-\frac{\bar{L}}{L}\right)}{\phi_{L}}+r^{*} \bar{k}+\left(\frac{k-\bar{k}}{\phi_{K}}\right) \bar{k} \text { if } \bar{k} \leq k .
\end{aligned}
$$

and:

$$
y_{D}=\mid \begin{aligned}
& p+r^{*} \bar{k}+\left(\frac{k-\bar{k}}{\phi_{K}}\right) k \text { if } \bar{k} \geq k, \\
& p+r^{*} \bar{k}+\left(\frac{k-\bar{k}}{\phi_{K}}\right) \bar{k} \text { if } \bar{k} \leq k .
\end{aligned}
$$

For a given $L$, we see that the income is always larger in a capital importing country than in a capital exporting one. The reason is that the after-tax return on capital is higher and overcompensates for the loss induced by the outflow benefiting foreign investors. Income per capita is independent of $L$ when labor mobility is infinite and independent of $k$ when capital mobility is infinite.

\subsection{The problem of the government}

The government maximizes a social welfare function that depends on private incomes and on average public spending net of transfers, denoted by $G$, divided by the size of the population $L+D .{ }^{15}$ Private incomes, $y_{L}$ and $y_{D}$, are weighted using the demographic weight of each type of agents, $L /(L+D)$ for workers and $D /(L+D)$ for pensioners, and a parameter $\gamma>0$ that reflects the weight of each pensioner relative to a worker, which can be measured by, for example, different participation rates in elections. The social welfare function of the government is given by:

\footnotetext{
15 Hence, public spending is not subject to returns to scale. It refers to, for example, education or healthcare spending rather than expenditure such as military spending. By making this assumption, we do not want to introduce an incentive for the government to increase the size of the economy.
} 


$$
U\left(\frac{L}{L+D} y_{L}+\gamma \frac{D}{L+D} y_{D}, \frac{G}{L+D}\right)
$$

where $U$ is an increasing and concave function in both arguments. Both partial derivatives, denoted $U_{Y}(.,$.$) and U_{G}(.,$.$) , are assumed to be infinite when the argu-$ ment equals zero. Finally, we assume that the budget is balanced and, consequently, that total public spending $G+p D$ is equal to total tax revenues:

$$
G+p D=\tau_{K} K+\tau_{L} L
$$

The government's problem then is to set $\tau_{K}$ and $\tau_{L}$ so as to maximize its utility function (11) subject to conditions (5), (7), (2), (3), and (12). Hence, tax rates $\tau_{K}, \tau_{L}$, productive factors $k, L$ and the production of public goods $G$ are all endogenously determined, whereas factor endowments $\bar{k}, \bar{L}$, pensioners' parameters $D, p$, and international remunerations $r^{*}, w^{*}$, are exogenous. Below, we use the superscript $o$ to identify the solutions of the optimization problem.

The derivation of the model is presented in Appendix A section. More specifically, Appendix A1 section details the optimization problem and Appendix A2 section discusses the issues of existence, uniqueness and continuity of the optimal solution. Denoting with an $o$ superscript the result of the optimization program, we demonstrate that countries with low capital endowment, $\bar{k}$, are net importers of capital $\left(k^{o}>\bar{k}\right)$, while those with high capital endowment are net capital exporters $\left(k^{o}<\bar{k}\right)$.

\subsection{Optimal tax rates}

As shown in Appendix A3 section, the optimal tax rate on capital satisfies:

$$
\tau_{K}^{o}=\mid \begin{aligned}
& \frac{1}{\phi_{k}}\left[(1-\eta) k^{o}+\eta\left(\bar{k}-k^{o}\right)\right] \text { if } \bar{k} \geq k^{o}, \\
& \frac{1}{\phi_{k}}\left[(1-\eta) \bar{k}+\left(k^{o}-\bar{k}\right)\right] \text { if } \bar{k} \leq k^{o} .
\end{aligned} \text { where: } \eta:=\frac{U_{Y}^{\prime}(., .)}{U_{G}^{\prime}(., .)} \frac{L+\gamma D}{L+D} .
$$

In the case of an equal weight to each inhabitant in the utility function (i.e. for $\gamma=1$ ), it can be shown (see Appendix A3 section) that there is an under-provision of public goods, i.e. that partial derivatives of the social welfare function satisfy $U_{Y}^{\prime}(.,)<.U_{G}^{\prime}(.$, .), which implies that $\eta<1$. Using expressions ( 13), we thus immediately conclude that the tax on capital is positive. It converges to zero for infinite capital mobility. For imperfect capital mobility, the tax rate depends on $k^{o}$ and on the value of $\eta$ at the optimal solution.

We first solve the model in the particular case where $D=0$ before moving to simulations for $D>0$. For $D=0$, it can be shown (see Appendix A2 section) that 
the marginal utilities of public and private goods are equal, i.e. $U_{Y}^{\prime}(.,)=.U_{G}^{\prime}(.,$.$) ,$ and we can conclude that $\eta=1$. Using (13), the optimal tax on capital is therefore:

$$
\left.\tau_{K}^{o}\right|_{D=0}=\mid \begin{aligned}
& \frac{\left(\bar{k}-k^{o}\right)}{\phi_{k}} \text { if } \bar{k} \geq k^{o}, \\
& \frac{\left(k^{o}-\bar{k}\right)}{\phi_{k}} \text { if } \bar{k} \leq k^{o},
\end{aligned}
$$

where $k^{o}$ is obtained (see Appendix A2 section), using (5), as the solution of:

$$
\begin{aligned}
& F_{K}^{\prime}(k, h)=r^{*} \text { if } \bar{k} \geq k, \\
& F_{K}^{\prime}(k, h)=r^{*}+\frac{2(k-\bar{k})}{\phi_{K}} \text { if } \bar{k} \leq k .
\end{aligned}
$$

Equation (15) states that the level of capital per worker $k$ is obtained by equalizing the marginal productivity of capital to the world's capital return $r^{*}$ if the country is a net exporter of capital (i.e. for $\bar{k}>k^{o}$ ). Conversely, we see that the marginal productivity of capital is larger than $r^{*}$ if the country is a net importer of capital $\left(\bar{k}<k^{o}\right)$. This asymmetry, which is a direct consequence of the assumption made concerning the differential remunerations of the net investment position, creates a rationale for different taxation depending on the net investment position of the country. Computing the effect of a change in the degree of mobility on the tax rate is then straightforward and gives:

$$
\frac{\left.\partial \tau_{K}^{o}\right|_{D=0}}{\partial \phi_{K}}=\mid \begin{aligned}
& -\frac{\left(\bar{k}-k^{o}\right)}{\phi_{k}^{2}} \text { if } \bar{k} \geq k^{o}, \\
& -\frac{\left(k^{o}-\bar{k}\right)}{\phi_{K}^{2}}\left[\frac{F_{K K}^{\prime \prime}\left(k^{o}, h\right)}{F_{K K}^{\prime \prime}\left(k^{o}, h\right)-\frac{2}{\phi_{K}}}\right] \text { if } \bar{k} \leq k^{o} .
\end{aligned}
$$

In both cases, the derivative is negative: an increase in capital mobility reduces the tax rate on capital (it triggers a race-to-the-bottom). However, the term under brackets in the second line of Eq. (16) is lower than unity. This implies that the derivative is larger, in absolute terms, for capital-exporting countries (first line) than for capital-importing ones (second line). For the latter case, capital mobility increases the capital per worker, thereby increasing the tax base and reducing the after-tax return premium: more capital mobility raises the taxation space of the capital-importing country. This key theoretical result is supported by the empirical analysis we present in Sect. 5. Concerning the effect of capital mobility on taxation of labor, provided the social welfare function is additively separable, we have (see Appendix A3 section for details):

$$
\frac{\left.\partial \tau_{L}^{o}\right|_{D=0}}{\partial \phi_{K}}=\frac{k^{o}\left(\bar{k}-k^{o}\right)}{\phi_{K}^{2}} \text { if } \bar{k} \geq k^{o} .
$$

For a capital-exporting country, capital mobility increases the tax rate on labor. This burden-shifting effect can be explained by the fact that the additional capital outflow triggered by higher capital mobility will be accompanied by an outflow of labor, since capital per worker (determined by $r^{*}$, see Eq. (15)) remains constant ex 
post. The labor tax base will therefore be reduced, and public spending will require a higher tax rate. For a capital-importing country, higher capital mobility triggers an inflow of capital that exceeds the inflow of labor (since capital per worker $k$ increases, see Eq. (15)). The net impact on labor taxation is ambiguous as it depends on how $k$ reacts to higher capital mobility (see Appendix A3 section for the derivation). We conclude that the burden shifting effect should be less pronounced in capital-importing countries than in capital-exporting ones.

\section{Model simulations}

We now consider the complete model with $D>0$, which is calibrated in order to simulate the impact of capital and labor mobility on tax rates. We first need to choose functional forms for the production and utility functions. We rely on a standard Cobb-Douglas production function:

$$
Y=F(K, h L)=K^{\alpha}(h L)^{1-\alpha},
$$

where $0 \leq \alpha \leq 1$ and $h>0$. In turn, we assume a log-linear utility function:

$$
U=\ln \left((1-\delta) y_{L}+\gamma \delta y_{D}\right)+\theta \ln (g),
$$

where $\delta=D /(D+L), \gamma$ is the weight of a pensioner relative to a worker in the social utility function, $g=G /(L+D)$ and $\theta>0$ represents the relative weight of the public good in social preferences.

\subsection{Calibration}

We calibrate the model on the four largest economies of the euro area: Germany, France, Italy and Spain, over the period of 1997-2017. All four countries have fully liberalized capital flows in the early 1990s, and their euro membership means that the frictions on capital markets from exchange-rate volatility are also similar. Furthermore, they have liberalized intra-EU labor flows over the 2000s, though not with the rest of the world. For each variable, we take the country average over 1997-2017 and then the average over the four countries, weighted by GDP.

The old-age dependency ratio $(d=D / L)$ is taken from the World Bank, Health Nutrition and Population Statistics, and is set to 27\%. Thus, the share of pensioners in the population is $\delta=D /(L+D)=0.21 .^{16}$

Gross disposable income of households (when aggregating workers and pensioners) is calibrated at $65 \%$ of GDP, based on the AMECO database of the European Commission. From the same database, we calculate that public pensions represent $13 \%$ of GDP, whereas public expenditure other than interpersonal transfers represents 35\% of GDP: $p D / Y=0.13, G / Y=0.35$, where $Y$ denotes GDP.

$\overline{{ }^{16} \text { Since } L \text { is endogenous, we set }} d$ and $\delta$ in terms of the labor endowment $\bar{L}$. 
Exogenous foreign factor returns $r^{*}$ and $w^{*}$ are calibrated based on the returns observed over the period for the four countries. According to Jordà et al. (2019), p. 1293, the post-1980 real return on wealth averaged $6.29 \%$ in Germany, $4.72 \%$ in France, $5.01 \%$ in Italy and $5.34 \%$ in Spain. We set $r^{*}=0.05$. From AMECO, we get a net worth per household of around 160,000 euros. We divide by 10,000 and set $\bar{k}=16$. We then recover $w^{*}$ based on the 0.7 labor share we get from AMECO, and using $r^{*} \bar{k}(1+d) / w^{*}=0.3 / 0.7$, we obtain $w^{*}=2.4$.

From AMECO, the ratio of public pensions to labor compensations is 0.27, i.e. $p D /(w L)=0.27$. Since $D / L=0.27$, we get $p=w$ : our simulation should yield a similar value for unit pension and unit wage.

Implicit tax rates are recovered from the European Commission's Taxation Trends database. Labor taxes represent $21 \%$ of GDP, whereas the share of corporate tax revenues is $2.7 \%$ of GDP. In our model, there are no other taxes. Since the budget constraint imposes that $\left(\tau_{K} K+\tau_{L} L\right) / Y=(G+p D) / Y=0.48$, we target $\tau_{K} K / Y=0.055$ and $\tau_{L} L / Y=0.425$.

Finally, the size of the workforce can be set at any level since it will just determine the size of the economy. We set $\bar{L}=100$.

The first line of Table 1 provides the values of the exogenous variables $\bar{L}, D=d \bar{L}$, $r^{*}, w^{*}$. In the second line, we report the target ratios that are used to calibrate the parameters of the model, the parameters being $\alpha, h, \gamma, p, \theta, \phi_{K}, \phi_{L}$. The third line provides two parameters that can be set without model simulations: $\alpha$ and $\gamma$. As already mentioned, the labor share is 0.7 in our sample; hence, we have $\alpha=0.3$. In our benchmark calibration, we also assume that the weight of the pensioners in the utility function is no higher than their share in the population of households: $\gamma=1$. The next line of the table reports the other parameters that are set such that the model solution is close to our five target ratios.

The second part of Table 1 reports the results of the simulated model in two different cases: the benchmark case, which corresponds to high capital endowment $(\bar{k}=16)$, and a variant with lower capital endowment $(\bar{k}=13)$. The endogenous ratios are close to their targets. The ratio of pensions to GDP is slightly lower, but rising $p$ would make the unit pension exceed the unit wage. As for labor taxation, it too is slightly below our calibrated value, but raising it would make $G / Y$ exceed its target.

Using our benchmark, high endowment case, we get $k<\bar{k}$ and are therefore in the case of a net capital-exporting country. The low endowment case yields $k>\bar{k}$, and we are in the case of a net capital importer.

\subsection{The impact of factor mobility on tax rates}

We can now simulate the model with different coefficients of capital mobility, $\phi_{K}$, and labor mobility, $\phi_{L}$. In each case, we successively simulate the model with $D=27$ and $\gamma=1$ (their calibrated values) and with a higher weight of pensioners either demographically $(D)$ or politically $(\gamma)$. 


\section{Capital mobility}

In this first group of simulations, we maintain the exogenous variables and parameters of Table 1 other than for $\phi_{K}$, which may change by $\pm 10 \%$. We then study how population ageing affects the results through a variant case where $D=30$ instead of 27. We also study how our results change when pensioners have a greater say in public decisions than workers (we set $\gamma=1.01$ instead of 1 in this case). The results are presented in Fig. 1 in the case of a net capital exporter (characterized by $\bar{k}=16$ and, for $\left.\phi_{K}=100, k=15.7\right)$ and in Fig. 2 for the case of a net capital importer $(\bar{k}=13$ and $k=13.4$ for $\left.\phi_{K}=100\right)$. In each case, we plot the evolution of the production factors $k$ and $L$, and of capital and labor tax revenues in percent of GDP $\left(\tau_{K} K / Y, \tau_{L} L / Y\right.$, respectively) as a function of capital mobility $\phi_{K}$. In both figures, the case with $D=27$ and $\gamma=1$ is depicted as solid black lines; dashed blue lines represent the case with more pensioners $(D=30)$, and the red crossed lines represent the case when each pensioner has greater influence over public decisions than each worker $(\gamma=1.01)$.

Figure 1 (the capital exporter case) illustrates the standard result when higher capital mobility triggers a reduction in capital taxation and a shift of the tax burden on to labor. Consistently, the labor force falls when the labor tax is endogenously raised, whereas the capital per resident increases. In the case of a net capital importer (Fig. 2), more capital mobility also triggers a reduction in capital taxation and a rise in labor taxation, but to a much lesser extent. When $\phi_{K}$ rises from 90 to 100 , capital taxation falls from $7.97 \%$ of GDP to $6.1 \%$ of GDP in the case of a capital exporter but only from 5.47 to $5.24 \%$ in the case of a capital importer. Simultaneously, labor taxation as a share of GDP rises from 37.0 to $38.7 \%$ in the former case, but only from 39.6 to $39.76 \%$ in the latter case.

Interestingly, the two types of countries differ in their reaction to population ageing (dashed blue lines), represented by more pensioners. A capital-importing country reacts to a higher dependence ratio by increasing the tax rate on labor (Fig. 2), whereas a capital-exporting country reacts by lowering the taxation of labor slightly (and increasing the tax rate on capital), as shown in Fig. 1. In both cases, the rising number of pensioners requires additional tax revenues. It also reduces the share of workers in the government's utility function. In a capital-importing country, though, the return on capital is higher than in the rest of the world, so the capital outflow following an increase in the tax rate on capital is relatively costly: it is better not to increase capital taxation. For a capital exporter, the cost of increasing capital taxation is less.

The result is different when population ageing is manifested by pensioners having a greater degree of political influence relative to workers. This is shown by the crossed red lines in Figs. 1 and 2, where $D$ is kept at its baseline level of 27 but $\gamma$ is raised to 1.01: in both types of countries, more powerful pensioners will put downward pressure on capital taxation, at the expense of higher labor taxation on workers. Importantly, the effect is greater in magnitude for a capital-exporting country than for a net capital importer. In our model, then, the influence of factors relating to the political economy of a nation, in addition to demographic forces, explains why ageing countries tend to cut capital taxation and shift the tax burden on to labor. Our model also supports our expectation that this effect would be more visible in a capital-exporting country. ${ }^{17}$

\footnotetext{
17 In our model, workers and pensioners have the same capital endowment. Alternatively, with higher capital endowment for the pensioners, population ageing could change the status of a country from capital importer to capital exporter.
} 
Table 1 Calibration. Source: Simulations with MATLAB

Exogenous variables

Targets ratios

Preset parameters

Calibrated parameters

Benchmark: high capita

Endogenous ratios

Production factors

Variant: low capital endowment $(\bar{k}=13)$

\begin{tabular}{|c|c|c|c|c|c|}
\hline Endogenous ratios & $\frac{p}{w}=1.12$ & $\frac{G}{Y}=0.3472$ & $\frac{p D}{Y}=0.1029$ & $\frac{\tau_{K} K}{Y}=0.0524$ & $\frac{\tau_{L} L}{Y}=0.3976$ \\
\hline Production factors & $k=13.4$ & $L=89.0$ & & & \\
\hline
\end{tabular}

(1)

(3)

(4)

(5)

\begin{tabular}{|c|c|c|c|c|}
\hline $\bar{L}=100$ & $D=27$ & $r^{*}=0.05$ & $w^{*}=2.4$ & \\
\hline$\frac{p}{w}=1$ & $\frac{G}{Y}=0.35$ & $\frac{p D}{Y}=0.13$ & $\frac{\tau_{K} K}{Y}=0.055$ & $\frac{\tau_{L} L}{Y}=0.425$ \\
\hline$=0.3$ & $\gamma=1$ & & & \\
\hline$=2$ & $p=1.3$ & $\theta=0.57$ & $1 \quad-10$ & $d-01$ \\
\hline
\end{tabular}

owment $(\bar{k}=16)$

$\frac{p D}{Y}=0.010 \quad \frac{\tau_{K} K}{Y}=0.061 \quad \frac{\tau_{L} L}{Y}=0.387$

$\frac{p}{w}=1.04 \quad \frac{G}{Y}=0.3510$

$L=89.7$
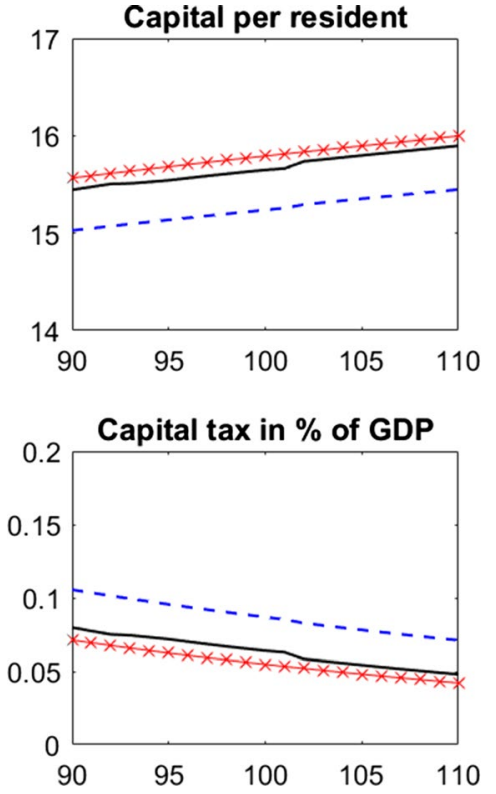

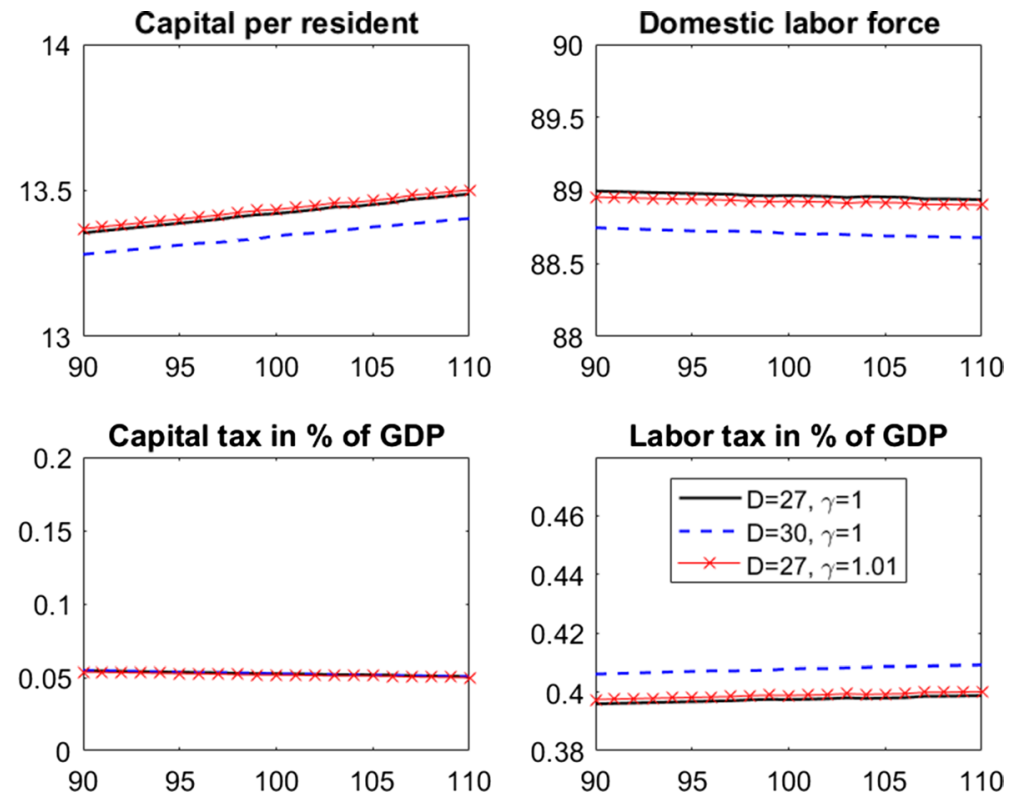

Fig. 2 Impact of capital mobility on taxation: net capital importer $(\bar{k}=13)$ Note: The horizontal axis represents different values of $\phi_{K}$. Source: Model simulations
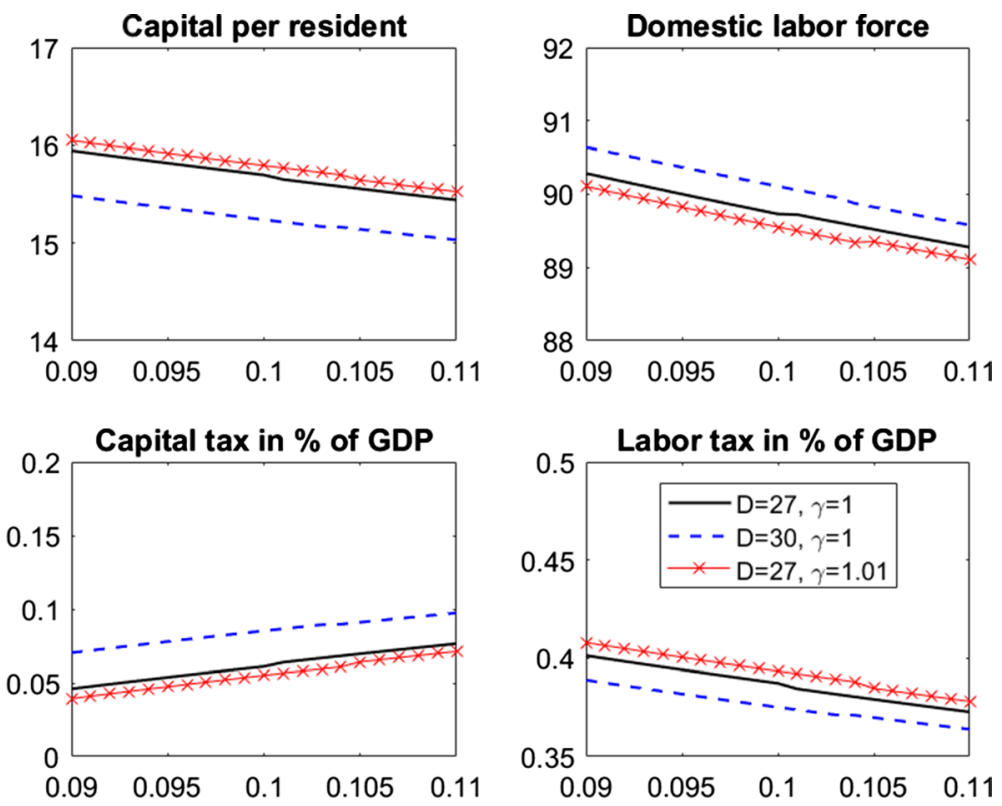

Fig. 3 Impact of labor mobility on taxation: net capital exporter $(\bar{k}=16)$ Note: The horizontal axis represents different values of $\phi_{L}$. Source: Model simulations 

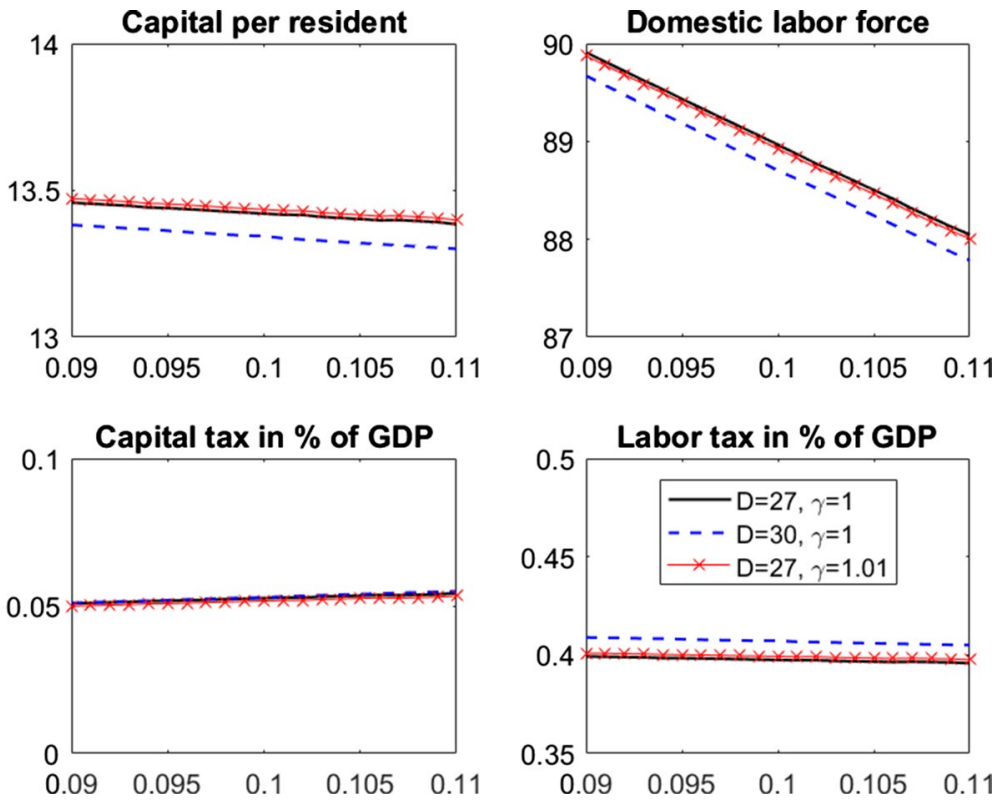

Fig. 4 Impact of labor mobility on taxation: net capital importer $(\bar{k}=13)$ Note: The horizontal axis represents different values of $\phi_{L}$. Source: Model simulations

nation. For a net capital importer, the private revenue loss from an increase in capital taxation is more important than that for a net capital exporter.

Again, population ageing leads the capital exporter to lower labor taxation and increase capital taxation, whereas when pensioners exert a higher degree of political influence relative to workers, we observe the reverse effect.

In all the simulations presented here, we have considered a net labor-exporting country $(L<\bar{L})$. For a net labor-importing country, we also find that increasing labor mobility puts downward pressure on labor taxation, with a burden shifting on to capital. ${ }^{18}$ We do not, therefore, find the same asymmetry between labor-exporters and labor-importers as for capital- exporters and capital importers. The reason is that labor cannot move without its capital endowment, whereas capital can move without its labor endowment: when labor becomes more mobile, it is extremely important for the country to keep its labor force (by cutting labor taxation) whatever the net position in terms of labor, because capital will move together with labor.

\footnotetext{
${ }^{18}$ We calibrate this case by assuming $w^{*}=1$ instead of 2.4. The economy is then close to balance in terms of capital. The figures can be found in Appendix B section.
} 


\section{Empirical strategy}

Our empirical methodology follows that of Adam and Kammas (2007), who estimate the impact of globalization on the effective tax rates on capital and labor for 17 OECD countries over the period of 1970-1997. They find that trade openness has a negative impact on capital taxation ("efficiency effect") but a positive impact on labor taxation ("compensation effect"). However, they only study the impact of trade openness and do not consider the impact of capital and/or labor mobility, and their sample period stops before the steep increase in capital mobility. ${ }^{19}$ We nevertheless follow their general methodology, consisting of panel estimations with country and time fixed effects, and a range of control variables including population ageing, public spending and government debt. In contrast to Adam and Kammas (2007), though, we consider trade openness as a control rather than a variable of interest, and we rely on specific proxies for capital and labor mobility.

Our panel covers 29 OECD countries ${ }^{20}$ over the period of 1997-2017. We use the following empirical specifications:

$$
\begin{aligned}
& \mathrm{KTAX}_{i t}=a_{1} \mathrm{KMOB}_{i t}+a_{2} \mathrm{LMOB}_{i t}+a_{3} X_{i t}+\mathrm{FE}_{i}+\mathrm{FE}_{t}+u_{i t}, \\
& \mathrm{LTAX}_{i t}=b_{1} \mathrm{LMOB}_{i t}+b_{2} \mathrm{KMOB}_{i t}+b_{3} X_{i t}+\mathrm{FE}_{i}+\mathrm{FE}_{t}+v_{i t},
\end{aligned}
$$

where $\mathrm{KTAX}_{i t}$ is the corporate income tax rate for country $i$ in year $t, \operatorname{LTAX}_{i t}$ the tax rate on labor, $\mathrm{KMOB}_{i t}$ is the mobility of capital, $\mathrm{LMOB}_{i t}$ is the mobility of labor, $X_{i t}$ is a vector of control variables, $\mathrm{FE}_{i}, \mathrm{FE}_{t}$ are country and time fixed effects, respectively, and $u_{i t}, v_{i t}$ are the residuals. Based on the existing theoretical literature, we expect $a_{1}, b_{1}<0$ ("race-to-the-bottom" effect for capital and labor taxation, respectively) and $a_{2}, b_{2}>0$ (compensation, or burden-shifting effect). However, we have shown theoretically that these effects may be influenced by the net international position of a country. Subsequently, we interact capital mobility and labor mobility with proxies of factor endowments.

We now briefly describe the data sources used in the analysis, with special attention paid to tax rates and to the variables used to capture factor mobility. ${ }^{21}$

\subsection{Tax rates}

Consistent with theoretical models of tax competition that focus on taxes deducted at source, the empirical literature on international tax competition has generally

\footnotetext{
19 The sample time period is especially important in our case. Indeed, Adam et al. (2013) show that studies incorporating more recent years tend to find a more negative impact of globalization on capital taxation.

20 Australia, Austria, Belgium, Canada, Chile, Czech Republic, Denmark, Finland, France, Germany, Hungary, Iceland, Ireland, Israel, Italy, Japan, South Korea, Mexico, the Netherlands, Norway, Poland, Portugal, Slovak Republic, Slovenia, Spain, Sweden, Switzerland, the UK, the USA.

21 A list of variables and data sources utilized is provided in Appendix C section.
} 
focused on corporate income tax and relied on the Effective Average Tax Rate (EATR), which accounts for tax allowances differing across countries (see Devereux \& Griffith, 1998). Adam et al. (2013) note that studies based on implicit tax rates (e.g. corporate income tax revenues divided by GDP or gross operating surplus) tend to find a positive relationship with globalization, but they are plagued with endogeneity problems.

We use EATRs from the 2018 update of the Oxford University Center for Business Taxation Tax Database developed by Bilicka and Devereux (2012). The EATR is calculated as the ratio of posttax to pretax net present value of a composite investment yielding a $20 \%$ pre-tax return financed through a combination of debt, equity and auto-financing.

As for the taxation of labor, we use the average tax wedge for a single individual with no children, earning a gross income representing $167 \%$ of average earnings. The tax wedge includes both the income tax and social security contributions paid and therefore offers a more complete picture of labor taxation than the statutory personal income tax rate. We choose to work on the tax rate applied on relatively high wages because labor mobility concerns mainly skilled labor across OECD countries. In the section of our paper dedicated to our robustness checks, we also study the determinants of the tax wedge at the median wage and at the minimum wage. The data are taken from the comparative tables of the OECD taxing wages database.

\subsection{Measures of factor mobility}

In their meta-analysis, Adam et al. (2013) highlight the importance of how globalization is measured for the estimation of its impact on capital taxation. Some studies have used trade openness or broader measures of globalization that also cover political and social aspects (Dreher, 2006). Other studies have focused specifically on international capital mobility. In the latter case, two categories of measures have been used: de jure (based on existing restrictions to capital flows as reported by the International Monetary Fund) or de facto (based on actual cross-border capital flows or stocks).

Figure 5 compares the evolution of de jure and de facto capital mobility for our sample of 29 OECD countries over the period of 1997-2017. The de jure measure is the index constructed by Chinn and Ito (2006), and regularly updated, based on the IMF's Annual Report on Exchange Arrangements and Exchange Restrictions. For de facto capital mobility, we calculate the sum of total assets and total liabilities of the international investment position (International Monetary Fund database) and divide by GDP in current dollars (World Bank database). The graph shows that, on average, our countries reach high de jure mobility very soon in our time sample, so the median and average of the de jure measures are almost flat. In contrast, the de facto measure shows a clear upward trend that only stabilizes after the global financial crisis. Since we intend to estimate the model in the within dimension, we select 
the de facto measure (denoted by KMOB), which offers the additional advantage of being more consistent with our measure of labor mobility.

Indeed, for labor mobility, there is no available de jure measure. The Migrant Integration Policy Index (MIPEX) developed by Huddleston et al. (2015) is a notable exception. Unfortunately, the index covers only a few years for a limited number of OECD countries. We therefore have to rely on a de facto measure based on international migration data. Since bilateral data on international migration are scarce, without a reliable source for population outflows, we have to rely on the yearly inflows of foreign population in percent of the total population of the home country, as reported by the OECD International Migration Database. ${ }^{22}$

Figure 6 compares the evolution of de facto capital and labor mobility in our dataset. On average, the increase in labor mobility is more than twofold from 1997 to 2017 , compared with more than threefold for capital mobility. ${ }^{23}$

The problem with using a unidirectional measure of labor mobility is potential endogeneity, since foreign labor may be attracted by lower tax rates. We address this problem by incorporating country fixed effects in the estimations and by instrumenting labor mobility with its first two lags. ${ }^{24}$

\subsection{Control variables}

Our first control variable is trade openness, denoted by TRADE, which is the sum of exports and imports of goods and services divided by twice the GDP, all variables being defined in current US dollar (OECD and World Bank databases). The square of TRADE is also introduced in order to capture a possible nonlinear impact of trade openness, consistent with the economic geography literature (Baldwin et al., 2003).

In advanced economies, financial integration has been accompanied with population ageing, which, as highlighted in our theoretical section, is likely to affect capital and labor taxation. We control for the share of the population aged 65 and over in the total population (65+ variable), using data from OECD population statistics. ${ }^{25}$

\footnotetext{
${ }^{22}$ For a subset of ten countries, there is consistent reporting of bilateral inflows over the whole time sample. For this subset, the correlation between total inflows and inflows from other OECD countries varies from $74 \%$ (Norway) to $97 \%$ (Spain). Hence, total inflows can be considered as a good proxy of inflows from other OECD countries.

23 The bump of labor mobility between 2004 and 2009 may be related to the two successive enlargements of the European Union in 2004 and 2007, with each time a two-year transitional period.

24 Clemens and Hunt (2017) argue that lagging the migrant-to-population ratio leads to a "blunt instrument" problem because the denominator of this ratio (total population) is almost constant from one year to the next. This generates spurious correlation between labor mobility and its lagged value. They rather recommend to use the lagged value of the numerator (migrations) as an instrument. In our case, though, instrumenting labor mobility with inward migration leads to a weak instrument problem.

25 We also ran specifications including political variables such as the presence of a right-wing executive or the share of seats in Parliament held by the governing party. These variables did not show up as significant.
} 
3.7

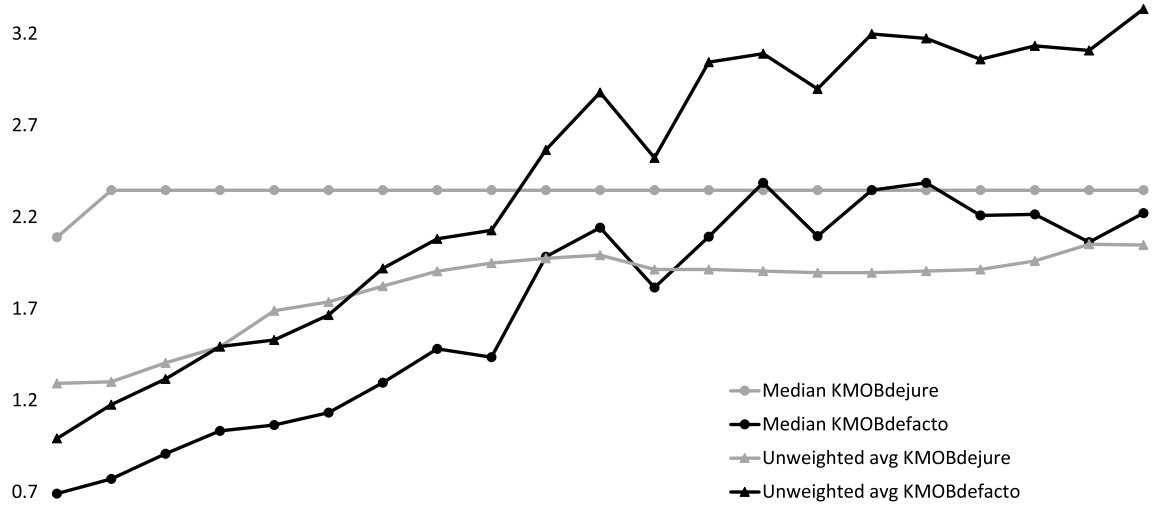

0.2

199719981999200020012002200320042005200620072008200920102011201220132014201520162017

Fig. 5 De jure and de facto capital mobility: unweighted averages, 29 OECD countries Note: Country sample: see Footnote 21. Source: Chinn and Ito (2006) and International Monetary Fund databases

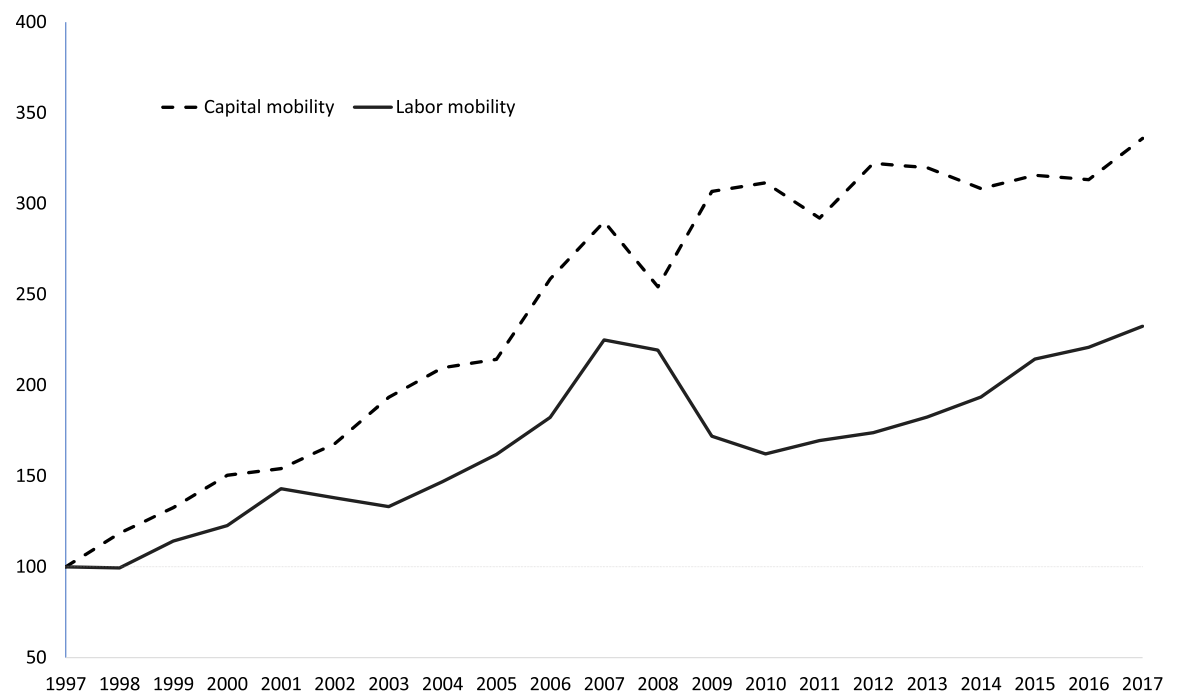

Fig. 6 De facto capital and labor mobility: Unweighted averages for 29 OECD countries (100 in 1997) Note: Capital mobility is the sum of total assets and liabilities in percent of GDP (Source: International Monetary Fund). Labor mobility is the ratio of immigration to total population (Source: OECD migration database) 
In order to account for a possible "compensation effect" of globalization whereby home workers would ask for more public spending in order to insure their income (Rodrik, 1998), we control for general government spending as a percent of GDP, GOVSPEND (IMF World Economic Outlook database). ${ }^{26}$ We also include the debtto-GDP ratio, GOVDEBT, in order to capture a debt brake effect, based on OECD and on national data sources. Both government spending and government debt are lagged to control for possible reverse causality.

\subsection{Factor endowments}

Whether a country is a net importer or exporter of productive capital can be observed through its net position in terms of Foreign Direct Investment-FDI (the difference between FDI assets and liabilities, which is therefore a positive figure for a net capital exporter). Alternatively, we could have used the overall net foreign asset position, but this would include sovereign assets and liabilities that do not fit our theoretical model, which assumes that budgets balance and restrict capital to productive capital.

The FDI data are from the International Monetary Fund. Since net FDI may be endogenous to taxation, we use the net stock in percent of GDP in the first year of the sample, hence at the end of 1997, and keep the same fixed proxy for the subsequent years. The variable is labeled FDI97. It is positive for a net capital-exporting country.

Table 2 reports the list of countries considered as capital exporters or importers according to the sign of FDI97. There are 13 capital exporters and 16 capital importers. Unsurprisingly, the most advanced economies are in the former group.

In our estimations, we either interact capital mobility with FDI97 directly or we interact it with a dummy variable, Kexp, that is equal to unity when FDI97 is positive, and zero otherwise. This strategy allows for a direct interpretation of the coefficient obtained.

Alternatively, we follow the approach of Hays (2003), who relies on capital per worker in a remote year as a proxy for the capital endowment. Accordingly, we use the stock of capital per worker in 1990, labeled k90 (Penn World Tables). ${ }^{27}$ A country with relatively high capital per worker in 1990 is likely to export capital in subsequent years.

For labor endowments, we rely on the 5-year average estimate of net migration between 1983 and 1987 divided by total population in 1990 (based on United Nations data). ${ }^{28}$ We use a dummy variable, Lexp, that is equal to unity when past

\footnotetext{
${ }^{26}$ Adam et al. (2013) show that including a measure of government spending in the regression significantly reduces the coefficient on globalization. It is therefore extremely important to control for government spending.

27 The data are not available for some of our countries before 1990.

28 The net inflows are generally calculated based on successive censuses, without disentangling inflows from outflows. As a result, UN data cannot be used to measure labor mobility, which would require data on gross flows rather than the balance between the two.
} 
net migration is negative (more outflows than inflows, suggesting high labor endowments), and zero otherwise. ${ }^{29}$

\subsection{Summary statistics}

Our sample includes 29 OECD countries from 1997 to 2017. However, some variables are missing at the beginning and/or at the end of the period for some countries. Table 3 provides an overview of the sample. The maximum number of observations $(29 \times 21=609)$ is obtained only for three variables. However, the sample is close to being balanced, with a minimum of 588 observations for the corporate income tax. The bottom of the table reports the statistics for those variables that are constant over time: capital per worker in 1990 (k90), the net FDI position in 1997 (FDI97) and the labor-exporter dummy (Lexp). Our sample is well-distributed around a zero FDI position, whereas a majority of countries are net labor-importers. ${ }^{30}$

\subsection{Instrumentation of labor mobility}

As previously described, our measure of labor mobility may be subject to endogeneity since, unlike for capital mobility, it is unidirectional. As a preliminary exercise, we regress capital and labor tax rates on trade openness (TRADE), squared trade openness (TRADE2), capital mobility (KMOB), labor mobility (LMOB), and on a set of control variables: lagged government spending (L.GOVSPEND), lagged government debt (L.GOVDEBT) and the dependency ratio of pensioners (65+). Country and time fixed effects are also included, and the standard errors are robust to heteroscedasticity. We subsequently compare the results with and without the instrumentation of labor mobility by its first two lags.

The results are reported in Appendix D section. The Hansen J tests suggest that the instruments are valid. In turn, the Kleibergen-Paap rk LM tests reject the null hypothesis of underidentification. Finally, the Kleibergen-Paap rk Wald F comfortably exceeds the value of 10 that is usually considered as the adequate threshold to reject the null hypothesis of weak instruments. The results with instrumented labor mobility are similar to those without but the coefficients display higher level of significance. Our empirical results presented in the following sections have all been obtained after instrumenting for labor mobility.

\footnotetext{
29 We also used the ratio of workers to total population in 1990 (from the Penn World Tables) as a proxy for labor endowments, but the results were nonsignificant.

${ }^{30}$ The labor-exporters in our sample are the following: Chile, Spain, Hungary, Ireland, Italy, Japan, Mexico, Poland, Portugal, Slovakia, hence 11 countries out of 29.
} 
Table 2 Capital exporters and importers. Source: Own calculations

Net capital exporters

(FDI97> 0)

Net capital importers

(FDI97<0)
Germany, Denmark, Finland, France, UK, Iceland, Italy, Japan, the Netherlands, Norway, Sweden, Switzerland, USA Australia, Austria, Belgium, Canada, Chile, Czech Rep., Spain, Hungary, Ireland, Israel, Korea, Mexico, Poland, Portugal, Slovakia, Slovenia
Table 3 Summary statistics: 29 OECD countries, 1997-2017. Source: Authors' database

\begin{tabular}{lrrlll}
\hline Variable & Obs & \multicolumn{1}{l}{ Mean } & SD & Min & Max \\
\hline KTAX & 588 & 0.245 & 0.068 & 0.086 & 0.477 \\
LTAX & 594 & 0.411 & 0.115 & 0.075 & 0.626 \\
TRADE & 609 & 0.423 & 0.194 & 0.092 & 1.128 \\
KMOB & 609 & 2.396 & 2.819 & 0.279 & 19.783 \\
LMOB & 589 & 0.006 & 0.005 & 0.000 & 0.034 \\
GOVSPEND & 602 & 0.419 & 0.093 & 0.142 & 0.651 \\
GOVDEBT & 608 & 0.682 & 0.370 & 0.039 & 2.228 \\
65+ & 609 & 0.150 & 0.037 & 0.046 & 0.277 \\
k90 & 29 & 0.208 & 0.084 & 0.054 & 0.336 \\
FDI97 & 29 & -0.017 & 0.140 & -0.358 & 0.318 \\
Lexp & 29 & 0.345 & 0.484 & 0 & 1 \\
\hline
\end{tabular}

\section{Empirical results}

We now present our main results (Sect. 5.1), which will then be used to quantify the impact of financial globalization on corporate tax rates (Sect. 5.2).

\subsection{The impact of factor endowments}

In our preliminary estimations (presented in Appendix D section), capital mobility has an insignificant or counterintuitive impact on taxation, while labor mobility has a positive impact on capital taxation (and an insignificant effect on labor taxation). Table 4 presents our results when capital mobility is interacted with the various proxies for capital-exporting status (k90, Kexp, FDI97) and labor mobility is interacted with our labor-exporting status variable (Lexp). We first discuss the impact of our control variables on taxation before moving on to the impact of factor mobility.

As expected, lagged government spending and lagged government debt both have a positive impact on taxation: for a given country, a rise in government spending (or government debt) above its 1997-2017 average (captured by the country fixed effect) and relative to the other countries in our sample (represented by the time fixed effect) puts upward pressure on both the corporate income tax and the labor tax wedge. Conversely, a higher share of the population aged 65 and above has an 


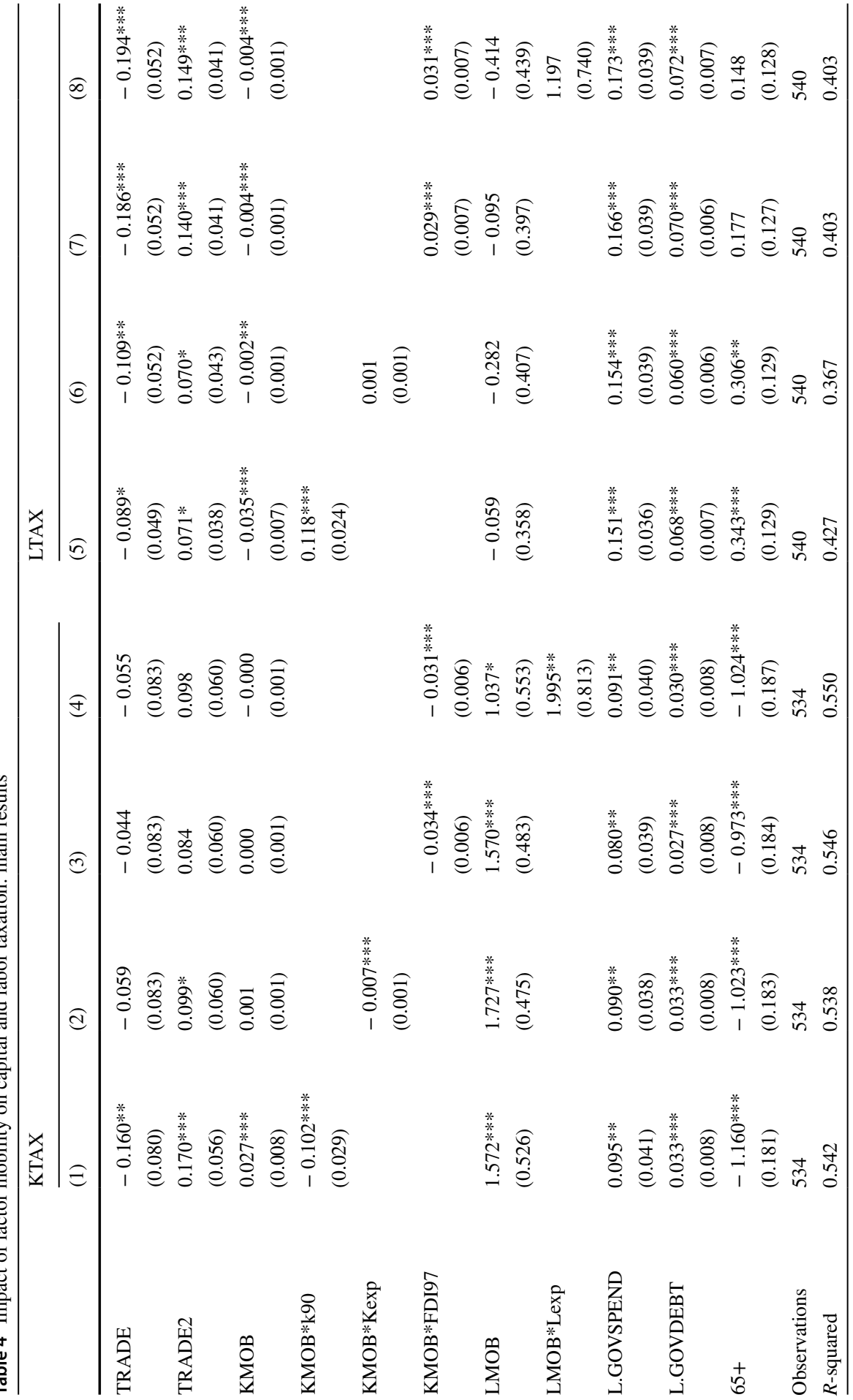




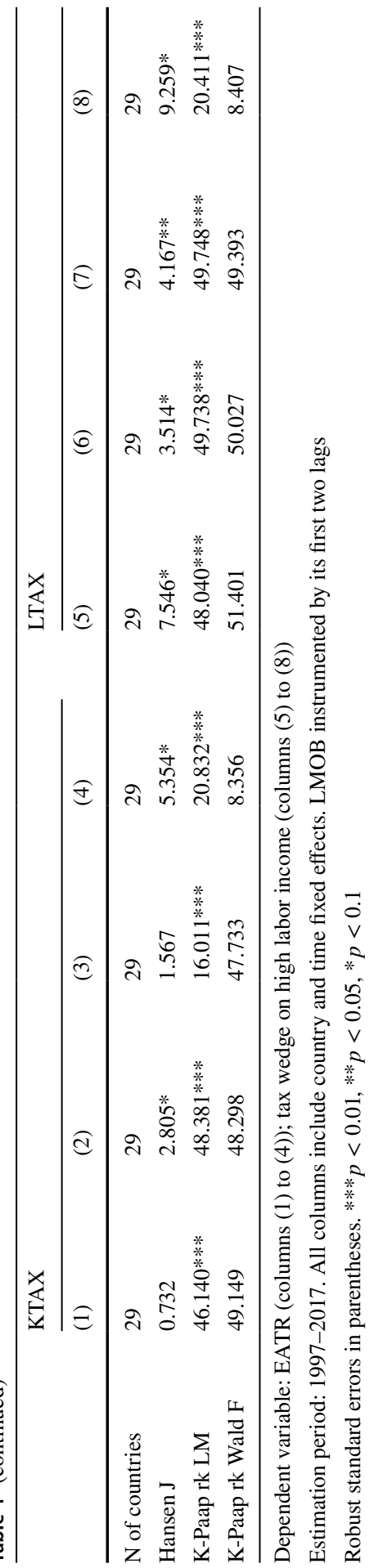


opposite effect on capital and labor taxation, respectively, with significant burdenshifting from the former to the latter.

Trade openness is found to affect both tax rates negatively, but this impact is weaker at higher levels of openness, becoming even positive in the case of capital taxation when trade openness is sufficiently large. This result is consistent with the economic geography literature: for low levels of openness (hence high transaction costs), production needs to be located close to the demand. Then, when the economy opens up, multinational firms start taking relative costs into account when locating their production, which puts downward pressure on taxation. However, for high levels of openness (hence low transaction costs), agglomeration forces become prominent and production becomes less sensitive to relative costs.

The impact of noninteracted capital mobility on corporate income tax rates is either positive (first column) or insignificant (next three columns). Once interacted with the capital exporter proxy or dummy, though, capital mobility has highly significant, negative impact on the capital tax. Symmetrically, noninteracted capital mobility has a negative impact on labor taxation, but the impact becomes positive for a capital-exporting country. Our results are, therefore, in line with the "race-to-the-bottom" and "burden-shifting" narratives, but only for capital exporters. The exact impact is nonetheless ambiguous, given the nonlinearity (see Sect. 5.2).

Labor mobility, on the other hand, affects capital taxation positively, though has an insignificant effect on labor taxation. Column (4) suggests that the positive impact of labor mobility on capital taxation is more marked for a labor-exporting country. The level of significance, however, is only $10 \%$, and the Kleibergen-Paap rk Wald F statistics suggests weak instruments in this regression.

\subsection{Quantification}

Based on our preferred specifications of Table 4, namely Columns (3) and (7), we can calculate the impact of individual variables on tax rates and their contributions to the variations observed over the past.

Table 3 provides the mean and standard variation (SD) of the different variables in our sample. Combined with Table 4, Column (3), we get that a 1 SD increase in LMOB increases the tax on capital by 0.8 percentage points $(1.57 \times 0.005=0.008)$. In turn, a $1 \mathrm{SD}$ increase in KMOB reduces the capital tax by $1.3 \mathrm{pp}(-0.034 \times 2.8 \times 0.14=-0.013)$ for a country whose FDI position in 1997 is $+14 \%$ of GDP (net capital exporter such as the Netherlands), whereas it increases the capital tax by $+1.3 \mathrm{pp}$ in a country with an initial FDI position of 
$-14 \%$ (net capital importer such as Mexico or Portugal). Similarly, the impact of KMOB and LMOB on the labor tax is given by Column (7). The coefficient on LMOB is nonsignificant. As for KMOB, a $1 \mathrm{SD}$ increase of it reduces the labor tax through the noninteracted coefficient by 1 pp $(-0.004 \times 2.8=-0.011)$. For a country with an initial FDI position of $+14 \%$ of GDP (net capital exporter), a 1 SD increase in KMOB has an additional effect of $+1.1 \mathrm{pp}(0.029 \times 2.8 \times 0.14=0.011)$. For such country, thus, the total effect of a 1 SD increase in KMOB on the labor tax is zero, whereas if the initial FDI position is $-14 \%$ (net capital importer), the total effect is $-2.2 \mathrm{pp}$.

In a second step, we calculate the contribution of each significant variable to the variation of both capital and labor tax rates between 2003 (the first year with a complete dataset) and 2017. The results are presented in Figs. 7 and 8 . The cumulative bars represent the contributions of the different variables, when they are significant, with the time fixed effects and the country-specific residuals being grouped together in the hatched bars. ${ }^{31}$

Other than for a subset of our sample countries (Switzerland, Hungary, Ireland, the Netherlands), the contribution of rising capital mobility to the variation of the corporate income tax (relative to the OECD sample) is negligible. It is negative for Switzerland and the Netherlands, but positive for Hungary and Ireland (these two countries being net capital importers). The contribution of labor mobility is generally positive, and occasionally larger (in absolute value), than that of capital mobility, but still relatively limited other than for Iceland and Slovenia. In fact, changes in the corporate income tax rate between 2003 and 2017 seem to be mostly driven by the growing share of those aged 65 and above in the population, and by a common trend.

In the case of the labor tax, labor mobility does not appear in the graph since it is not significant in Column (7) of Table 4. Rising capital mobility contributes negatively to the change in labor taxation in Ireland and Hungary. For our other sample countries, the effect is minor relative to the contribution of rising government debt and, for certain countries, the impact of trade opening up. As for capital taxation, there is a common downward trend in tax rates.

\section{Robustness}

In this section, four robustness tests are presented in succession. First, we check whether our results are robust to excluding certain countries. Second, we estimate a dynamic specification. Third, we perform similar estimations for labor taxation at lower levels of income and for changes in value-added tax. Finally, we check whether interacting the dependency ratio of pensioners in the population with the

\footnotetext{
31 The capital exporter or importer status is fixed at its 1997 level. Only three countries in our sample have switched from capital-exporting to capital-importing or vice versa over the period: Ireland, Luxembourg and the USA. Due to the time fixed effects, the hatched bars are relatively large and they generally point downward in both graphs.
} 


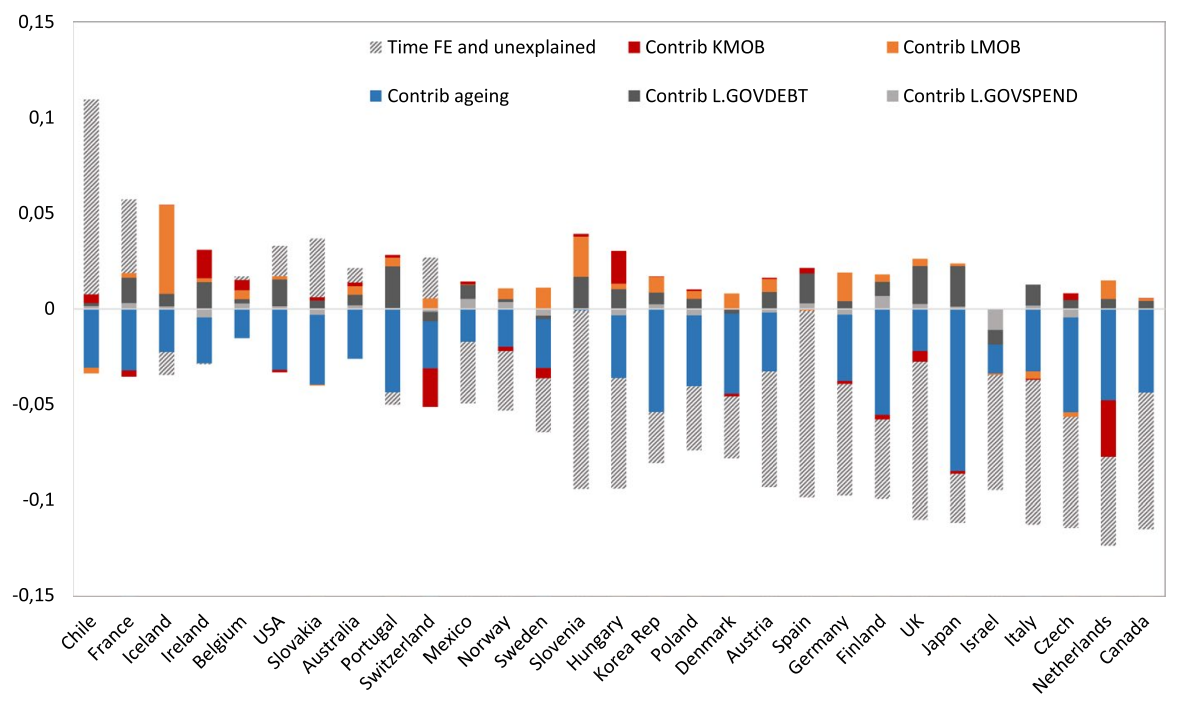

Fig. 7 Contributions to changes in capital taxation, 2003-2017 Source: Authors' calculations based on Table 4, Column (3)

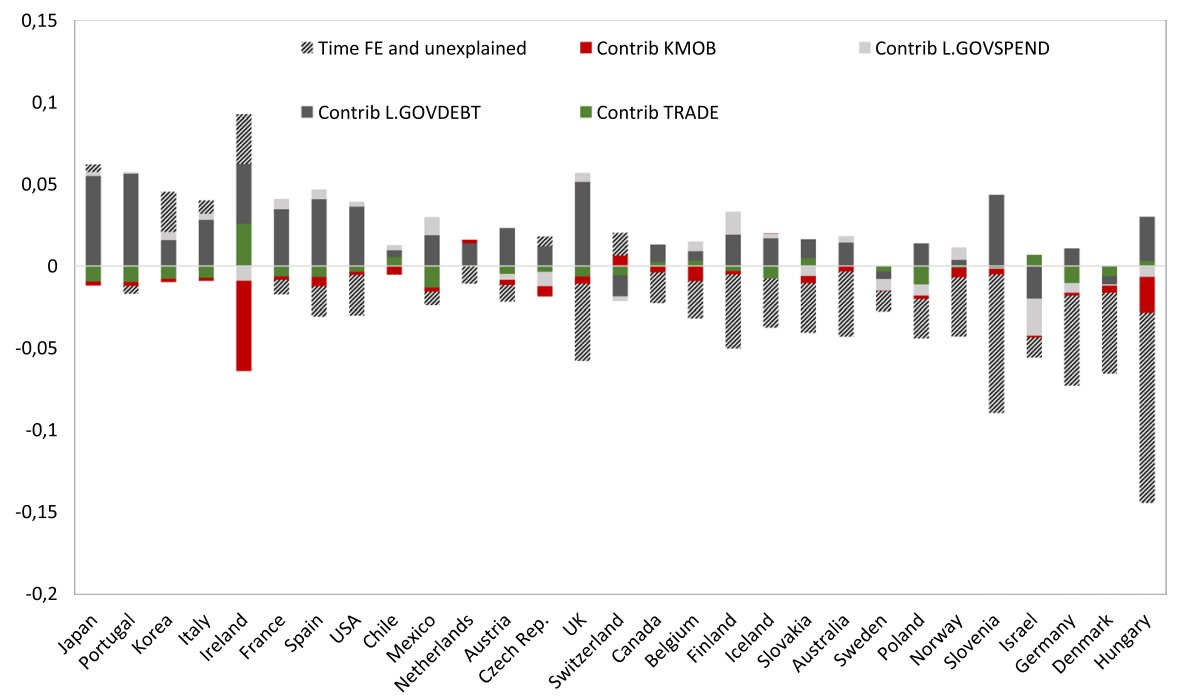

Fig. 8 Contributions to changes in labor taxation, 2003-2017 Source: Authors' calculations based on Table 4, Column (7) 
Table 5 Robustness: excluding some countries

\begin{tabular}{|c|c|c|c|c|}
\hline & \multicolumn{2}{|l|}{ KTAX } & \multicolumn{2}{|l|}{ LTAX } \\
\hline & $\begin{array}{l}\text { w/o CHE, IRL, NDL } \\
\text { (1) }\end{array}$ & $\begin{array}{l}\text { w/o HUN, USA } \\
\text { (2) }\end{array}$ & $\begin{array}{l}\text { w/o CHE, IRL, NDL } \\
\text { (3) }\end{array}$ & $\begin{array}{l}\text { w/o HUN, USA } \\
\text { (4) }\end{array}$ \\
\hline TRADE & $\begin{array}{l}-0.158 * \\
(0.094)\end{array}$ & $\begin{array}{l}-0.042 \\
(0.083)\end{array}$ & $\begin{array}{l}-0.097 \\
(0.062)\end{array}$ & $\begin{array}{l}-0.220 * * * \\
(0.044)\end{array}$ \\
\hline TRADE2 & $\begin{array}{l}0.179 * * \\
(0.074)\end{array}$ & $\begin{array}{l}0.075 \\
(0.061)\end{array}$ & $\begin{array}{l}0.060 \\
(0.053)\end{array}$ & $\begin{array}{l}0.178^{* * * *} \\
(0.033)\end{array}$ \\
\hline KMOB & $\begin{array}{l}-0.002 \\
(0.002)\end{array}$ & $\begin{array}{l}0.000 \\
(0.001)\end{array}$ & $\begin{array}{l}-0.010 * * * \\
(0.002)\end{array}$ & $\begin{array}{l}-0.004 * * * \\
(0.001)\end{array}$ \\
\hline KMOB*FDI97 & $\begin{array}{l}-0.039 * * * \\
(0.013)\end{array}$ & $\begin{array}{l}-0.026^{* * *} \\
(0.006)\end{array}$ & $\begin{array}{l}0.033^{*} \\
(0.017)\end{array}$ & $\begin{array}{l}0.017 * * * \\
(0.006)\end{array}$ \\
\hline LMOB & $\begin{array}{l}1.610 * * * \\
(0.505)\end{array}$ & $\begin{array}{l}1.611 * * * \\
(0.475)\end{array}$ & $\begin{array}{l}-0.013 \\
(0.380)\end{array}$ & $\begin{array}{l}-0.089 \\
(0.386)\end{array}$ \\
\hline L.GOVSPEND & $\begin{array}{l}0.106^{* *} \\
(0.050)\end{array}$ & $\begin{array}{l}0.084 * * \\
(0.039)\end{array}$ & $\begin{array}{l}0.225 * * * \\
(0.044)\end{array}$ & $\begin{array}{l}0.147 * * * \\
(0.036)\end{array}$ \\
\hline L.GOVDEBT & $\begin{array}{l}0.042 * * * \\
(0.010)\end{array}$ & $\begin{array}{l}0.025^{* * * *} \\
(0.009)\end{array}$ & $\begin{array}{l}0.066^{* * * *} \\
(0.008)\end{array}$ & $\begin{array}{l}0.073 * * * \\
(0.007)\end{array}$ \\
\hline $65+$ & $\begin{array}{l}-0.931 * * * \\
(0.182)\end{array}$ & $\begin{array}{l}-0.962 * * * \\
(0.188)\end{array}$ & $\begin{array}{l}0.142 \\
(0.121)\end{array}$ & $\begin{array}{l}0.180 \\
(0.125)\end{array}$ \\
\hline Observations & 474 & 498 & 484 & 506 \\
\hline$R$-squared & 0.534 & 0.563 & 0.446 & 0.463 \\
\hline N. of countries & 26 & 27 & 26 & 27 \\
\hline Hansen J & 0.443 & 2.071 & $4.184^{* *}$ & $4.865^{* *}$ \\
\hline K-Paap rk LM & $33.972 * * *$ & $48.494 * * *$ & $35.886^{* * *}$ & $49.909 * * *$ \\
\hline K-Paap rk Wald F & 37.408 & 48.298 & 39.657 & 50.052 \\
\hline
\end{tabular}

Dependent variable: EATR (col. (1)-(2)); tax wedge on high labor income (col. (3)-(4))

Estimation period: 1997-2017. All columns include country and time fixed effects. LMOB instrumented Robust standard errors in parentheses. $* * * p<0.01, * * p<0.05, * p<0.1$

international capital status (as implied by our theoretical estimation) changes our results.

\subsection{Excluding certain countries}

We first test whether our results are robust to excluding certain countries from the sample. More specifically, we successively remove the following groups of countries: 
- Potential tax havens, where our theoretical model may not apply due to a gap between the corporate tax base and the stock of physical capital: Ireland, the Netherlands, Switzerland;

- Countries with citizenship taxation, where our theoretical model may not apply due to a gap between the personal income tax base and the resident population: Hungary, the USA.

The results are presented in Table 5. We only report the estimations carried out with the net FDI position in 1997 as a proxy for capital-exporting/-importing status, and without interacting labor mobility with a measure of labor-exporting/-importing status. The nonlinear impact of capital mobility on both tax rates, depending on the net FDI position, is confirmed, and the effects of capital mobility on capital and labor taxation respectively have opposite signs. As for labor mobility, it still affects capital taxation positively, without any significant impact on labor taxation. ${ }^{32}$

\subsection{Dynamic model}

In our theoretical model, imperfect factor mobility translates into wedges between domestic after-tax returns and their world levels. The wedge declines following an increase in factor mobility. Accordingly, after-tax returns should converge over time to the world level when capital and/or labor mobility increases. It follows, then, that countries starting with higher tax rates on capital at the beginning of the sample period should see their rates decline more rapidly over time, especially if they are capital exporters.

In order to test for conditional convergence, we estimate the following dynamic model:

$$
\Delta \mathrm{TAX}_{i t}=\rho \mathrm{TAX}_{i t-1}+\beta X_{i t}+\mathrm{FE}_{i}+\mathrm{FE}_{t}+u_{i t},
$$

where TAX stands for either the capital or the labor tax, $\Delta$ is the first-difference operator, $X_{i t}$ is the vector of control variables described above and $\mathrm{FE}_{i}, \mathrm{FE}_{t}$ are country and time fixed effects. We expect $\rho<0$, implying that higher tax rates tend to decline faster over time. Equation (22) can be estimated as an autoregressive equation (estimating $1+\rho$ instead of $\rho$ ). To avoid the bias arising from the correlation between the lagged dependent variable and the fixed effect (Nickell, 1981), Eq. (22) could be estimated through a GMM panel. However, the extent to which the Nickell bias should be taken into account depends on $T$ (number of time periods) relative to $N$ (number of individuals, here countries). In our case, we have $T=21$ and $N=29$, which according to Roodman (2009) are, respectively, "large" and "small." 33 Estimating Eq. (22) through system $\mathrm{GMM}^{34}$ increases the number of instruments

\footnotetext{
32 We note that the Hansen $\mathrm{J}$ test statistic casts some doubt on the instrumentation for this latter estimation.

33 As argued by Roodman (2009), GMM estimators have been designed for samples with a large number of individuals $N$ (typically several thousands or even million) and a small number of years $T$. In our macro-panel case, $T$ is relatively large, but $N$ is extremely small.

${ }^{34}$ System GMM is to be preferred to difference GMM when the variables are persistent.
} 
(whose consequence is a perfect 1.000 -value for the Hansen $\mathrm{J}$ test of overidentification), even when we keep the number as small as possible and use the orthogonal deviation methodology in order not to lose too many observations due to the lags. The problem could be solved by dropping the time fixed effects. However, doing so would likely invalidate the autocorrelation tests that rely on the assumption of no correlation across countries.

We therefore decided to run the estimations through panel fixed effects, acknowledging the likely underestimation of the autoregressive coefficient. The results are reported in Table 6. Columns (1)-(3) concern capital taxation, whereas (4)-(6) are for labor taxation. In all cases, the lagged dependent variable is positive, significant and lower than unity. With an autoregressive coefficient of 0.7 to 0.8 , the half-life of the adjustment is of 2-3 years, although this is a lower bound due to the possible estimation bias. $^{35}$

We find the impact of capital mobility to be significantly negative when interacted with the net FDI position in 1997: only in net capital-exporting countries does capital mobility accelerate the downward convergence of the capital tax. For the labor tax equation, we find a similar convergence speed, but factor mobility does not play a significant role in impacting labor taxation.

On the whole, despite the very demanding specification that features an autoregressive term together with both country and time fixed effects, we find some evidence confirming that capital mobility puts more pressure on corporate income tax rates in capital-exporting countries than in capital-importing ones.

\subsection{Other taxes}

Our third exercise is to test for the impact of capital and labor mobility on the standard rate of the value-added tax (VAT) or of the general sales tax, and on the tax wedge at lower levels of labor income: median wage (LTAX med) and minimum wage (LTAX min). The results are presented in Table $7 .{ }^{36}$

Capital mobility is found to put upward pressure on the VAT rate, especially in capital-exporting countries. It has no significant impact on the tax wedge at the median wage, and a negative effect on the tax wedge at the minimum wage. While the result for VAT is consistent with burden shifting onto an immobile tax base, in the case of the tax wedge at the minimum wage, the result may come from an indirect channel related to low-skilled workers obtaining a more protective social safety net when globalization makes their income more uncertain (Rodrik, 1998).

In turn, labor mobility has no significant impact except for the tax wedge at the minimum wage. In this case, though, the Hansen $\mathbf{J}$ test rejects the validity of the instrumentation. We conclude, therefore, that labor mobility has no robust impact on the three tax rates.

\footnotetext{
35 The half-life is calculated as $H=\frac{-\ln 2}{\ln (1+\rho)}$, where $(1+\rho)$ is the autoregressive coefficient.

${ }^{36}$ The estimation is still run for 29 countries. However, due to data limitations, we have substituted Turkey for Chile.
} 
Table 6 Robustness: dynamic panel estimation

\begin{tabular}{|c|c|c|c|c|c|c|}
\hline \multirow[t]{2}{*}{ VARIABLES } & \multicolumn{3}{|l|}{ KTAX } & \multicolumn{3}{|l|}{ LTAX } \\
\hline & (1) & (2) & (3) & (4) & (5) & (6) \\
\hline L.KTAX & $\begin{array}{l}0.767 * * * \\
(0.043)\end{array}$ & $\begin{array}{l}0.757 * * * \\
(0.045)\end{array}$ & $\begin{array}{l}0.763 * * * \\
(0.045)\end{array}$ & & & \\
\hline L.LTAX & & & & $\begin{array}{l}0.754 * * * \\
(0.055)\end{array}$ & $\begin{array}{l}0.743 * * * \\
(0.054)\end{array}$ & $\begin{array}{l}0.746 * * * \\
(0.054)\end{array}$ \\
\hline TRADE & $\begin{array}{l}-0.002 \\
(0.039)\end{array}$ & $\begin{array}{l}0.017 \\
(0.042)\end{array}$ & & $\begin{array}{l}-0.002 \\
(0.031)\end{array}$ & $\begin{array}{l}-0.020 \\
(0.032)\end{array}$ & \\
\hline TRADE2 & $\begin{array}{l}0.032 \\
(0.030)\end{array}$ & $\begin{array}{l}0.015 \\
(0.033)\end{array}$ & & $\begin{array}{l}-0.001 \\
(0.023)\end{array}$ & $\begin{array}{l}0.015 \\
(0.026)\end{array}$ & \\
\hline LMOB & $\begin{array}{l}0.523 * \\
(0.306)\end{array}$ & $\begin{array}{l}0.502 * \\
(0.303)\end{array}$ & $\begin{array}{l}0.347 \\
(0.297)\end{array}$ & $\begin{array}{l}-0.316 \\
(0.231)\end{array}$ & $\begin{array}{l}-0.277 \\
(0.231)\end{array}$ & $\begin{array}{l}-0.301 \\
(0.217)\end{array}$ \\
\hline KMOB & $\begin{array}{l}-0.001 \\
(0.001)\end{array}$ & $\begin{array}{l}-0.000 \\
(0.001)\end{array}$ & $\begin{array}{l}0.000 \\
(0.000)\end{array}$ & $\begin{array}{l}0.000 \\
(0.001)\end{array}$ & $\begin{array}{l}-0.001 \\
(0.001)\end{array}$ & $\begin{array}{l}-0.000 \\
(0.001)\end{array}$ \\
\hline KMOB*FDI97 & & $\begin{array}{l}-0.007^{*} \\
(0.004)\end{array}$ & $\begin{array}{l}-0.009 * * \\
(0.004)\end{array}$ & & $\begin{array}{l}0.006 \\
(0.006)\end{array}$ & $\begin{array}{l}0.005 \\
(0.005)\end{array}$ \\
\hline L.GOVSPEND & $\begin{array}{l}0.002 \\
(0.023)\end{array}$ & $\begin{array}{l}0.000 \\
(0.023)\end{array}$ & $\begin{array}{l}-0.012 \\
(0.021)\end{array}$ & $\begin{array}{l}0.078 * * * \\
(0.022)\end{array}$ & $\begin{array}{l}0.081 * * * \\
(0.022)\end{array}$ & $\begin{array}{l}0.079 * * * \\
(0.021)\end{array}$ \\
\hline L.GOVDEBT & $\begin{array}{l}0.010 * \\
(0.005)\end{array}$ & $\begin{array}{l}0.007 \\
(0.005)\end{array}$ & $\begin{array}{l}0.008 \\
(0.005)\end{array}$ & $\begin{array}{l}0.007 \\
(0.006)\end{array}$ & $\begin{array}{l}0.010 * \\
(0.005)\end{array}$ & $\begin{array}{l}0.009 * \\
(0.005)\end{array}$ \\
\hline $65+$ & $\begin{array}{l}-0.234^{*} \\
(0.120)\end{array}$ & $\begin{array}{l}-0.212^{*} \\
(0.120)\end{array}$ & $\begin{array}{l}-0.180 \\
(0.117)\end{array}$ & $\begin{array}{l}-0.0192 \\
(0.086)\end{array}$ & $\begin{array}{l}-0.0432 \\
(0.080)\end{array}$ & $\begin{array}{l}-0.0482 \\
(0.080)\end{array}$ \\
\hline Observations & 529 & 529 & 529 & 540 & 540 & 540 \\
\hline$R$-squared & 0.828 & 0.829 & 0.826 & 0.760 & 0.761 & 0.761 \\
\hline N. of countries & 29 & 29 & 29 & 29 & 29 & 29 \\
\hline Hansen $\mathbf{J}$ & 0.891 & 0.819 & 0.680 & $5.094 * *$ & $5.363 * *$ & $5.024 * *$ \\
\hline Kleibergen-Paap rk LM & $47.135^{* * *}$ & $47.489 * * *$ & $46.912 * * *$ & $48.974 * * *$ & $49.424 * * *$ & $48.847 * * *$ \\
\hline Kleibergen-Paap rk Wald F & 46.173 & 46.180 & 50.717 & 49.640 & 49.033 & 53.743 \\
\hline
\end{tabular}

Dependent variable: EATR (col. (1)-(3)); tax wedge on high labor income (col. (4)-(6))

Estimation period: 1997-2017. All columns include country and time fixed effects. LMOB instrumented Robust std errors in parentheses. $* * * p<0.01$, ** $p<0.05, * p<0.1$

\subsection{Inspecting ageing}

Our final robustness exercise involves interacting the old dependency ratio with the international capital status of the country. Based on our theoretical simulations (Sect. 3), we expect net capital exporters to react more to population ageing especially when ageing is not just a demographic change but also involves a change in the political influence of pensioners relative to workers. We replicate our baseline estimations, but now interact the share of the older population with the net FDI position in 1997 (using the values of the dummy and at levels, successively). The results are reported in Table 8 . The results for the noninteracted $65+$ variable are 
Table 7 Impact of factor mobility on VAT and taxation of medium/low wages

\begin{tabular}{|c|c|c|c|c|c|c|}
\hline & \multicolumn{2}{|l|}{ VAT } & \multicolumn{2}{|l|}{ LTAX med } & \multicolumn{2}{|l|}{ LTAX min } \\
\hline & (1) & (2) & (3) & (4) & (5) & (6) \\
\hline TRADE & $\begin{array}{l}0.014 \\
(0.029)\end{array}$ & $\begin{array}{l}0.012 \\
(0.029)\end{array}$ & $\begin{array}{l}0.061 \\
(0.055)\end{array}$ & $\begin{array}{l}0.020 \\
(0.054)\end{array}$ & $\begin{array}{l}-0.092 \\
(0.060)\end{array}$ & $\begin{array}{l}-0.090 \\
(0.058)\end{array}$ \\
\hline TRADE2 & $\begin{array}{l}-0.044^{* *} \\
(0.022)\end{array}$ & $\begin{array}{l}-0.042^{*} \\
(0.022)\end{array}$ & $\begin{array}{l}-0.022 \\
(0.043)\end{array}$ & $\begin{array}{l}0.013 \\
(0.041)\end{array}$ & $\begin{array}{l}0.091^{*} \\
(0.047)\end{array}$ & $\begin{array}{l}0.088^{*} \\
(0.046)\end{array}$ \\
\hline КМOB & $\begin{array}{l}0.0014 * * * \\
(0.001)\end{array}$ & $\begin{array}{l}0.0016^{* * * *} \\
(0.000)\end{array}$ & $\begin{array}{l}-0.000 \\
(0.001)\end{array}$ & $\begin{array}{l}-0.002 * \\
(0.001)\end{array}$ & $\begin{array}{l}-0.006 * * * \\
(0.002)\end{array}$ & $\begin{array}{l}-0.007 * * * \\
(0.001)\end{array}$ \\
\hline KMOB*Kexp & $\begin{array}{l}0.001^{* *} \\
(0.0005)\end{array}$ & & $\begin{array}{l}-0.001 \\
(0.001)\end{array}$ & & $\begin{array}{l}-0.002 \\
(0.002)\end{array}$ & \\
\hline KMOB*FDI97 & & $\begin{array}{l}0.006^{*} \\
(0.003)\end{array}$ & & $\begin{array}{l}0.010 \\
(0.006)\end{array}$ & & $\begin{array}{l}-0.011 \\
(0.007)\end{array}$ \\
\hline LMOB & $\begin{array}{l}-0.236 \\
(0.196)\end{array}$ & $\begin{array}{l}-0.212 \\
(0.200)\end{array}$ & $\begin{array}{l}-0.051 \\
(0.340)\end{array}$ & $\begin{array}{l}-0.010 \\
(0.339)\end{array}$ & $\begin{array}{l}0.931 \text { ** } \\
(0.431)\end{array}$ & $\begin{array}{l}0.882^{* *} \\
(0.423)\end{array}$ \\
\hline L.GOVSPEND & $\begin{array}{l}-0.028 \\
(0.018)\end{array}$ & $\begin{array}{l}-0.026 \\
(0.018)\end{array}$ & $\begin{array}{l}0.139 * * * \\
(0.038)\end{array}$ & $\begin{array}{l}0.142 * * * \\
(0.038)\end{array}$ & $\begin{array}{l}0.161 * * * \\
(0.041)\end{array}$ & $\begin{array}{l}0.158 * * * \\
(0.041)\end{array}$ \\
\hline L.GOVDEBT & $\begin{array}{l}0.029 * * * \\
(0.004)\end{array}$ & $\begin{array}{l}0.030^{* * *} \\
(0.004)\end{array}$ & $\begin{array}{l}0.032 * * * \\
(0.006)\end{array}$ & $\begin{array}{l}0.038^{* * *} \\
(0.006)\end{array}$ & $\begin{array}{l}0.060^{* * *} \\
(0.008)\end{array}$ & $\begin{array}{l}0.058^{* * *} \\
(0.008)\end{array}$ \\
\hline $65+$ & $\begin{array}{l}0.048 \\
(0.073)\end{array}$ & $\begin{array}{l}0.042 \\
(0.075)\end{array}$ & $\begin{array}{l}0.256^{* * *} \\
(0.121)\end{array}$ & $\begin{array}{l}0.189 \\
(0.123)\end{array}$ & $\begin{array}{l}0.112 \\
(0.156)\end{array}$ & $\begin{array}{l}0.125 \\
(0.155)\end{array}$ \\
\hline Observations & 526 & 526 & 504 & 504 & 540 & 540 \\
\hline$R$-squared & 0.407 & 0.409 & 0.296 & 0.300 & 0.364 & 0.365 \\
\hline N. of countries & 29 & 29 & 29 & 29 & 29 & 29 \\
\hline Hansen $\mathbf{J}$ & 1.587 & 1.293 & 1.282 & 1.434 & $6.983 * * *$ & $6.413^{* *}$ \\
\hline Kleibergen-Paap rk LM & $48.995^{* * *}$ & $48.974 * * *$ & $44.491 * * *$ & $45.073 * * *$ & $49.738 * * *$ & 49.748 \\
\hline Kleibergen-Paap rk Wald F & 49.040 & 48.440 & 44.029 & 44.239 & 50.027 & 49.393 \\
\hline
\end{tabular}

Dependent variable: standard VAT rate (Col. (1)-(2)); tax wedge at median wage (col. (3)-(4)); tax wedge at min. wage (col. (5)-(6)). Estimation period: 1997-2017. Chile excluded, Turkey included All columns include country and time fixed effects. LMOB instrumented. Robust std errors in parentheses

$* * * p<0.01, * * p<0.05, * p<0.1$

unchanged. Once interacted with the international capital status, the share of the $65+$ population has no significant impact, other than in column (4), where the coefficient is significantly positive: in capital-exporting countries, population ageing tends to put upward pressure on the labor tax. This result is consistent with our theoretical simulations if ageing is not considered as a pure demographic trend but also as a change in social preferences. The results for capital mobility, labor mobility and the other control variables remain unchanged. 
Table 8 Ageing in capital-exporting countries

\begin{tabular}{|c|c|c|c|c|}
\hline & \multicolumn{2}{|l|}{ KTAX } & \multicolumn{2}{|l|}{ LTAX } \\
\hline & (1) & (2) & (3) & (4) \\
\hline TRADE & $\begin{array}{l}-0.056 \\
(0.082)\end{array}$ & $\begin{array}{l}-0.043 \\
(0.081)\end{array}$ & $\begin{array}{l}-0.112^{* *} \\
(0.051)\end{array}$ & $\begin{array}{l}-0.190^{* * * *} \\
(0.051)\end{array}$ \\
\hline TRADE2 & $\begin{array}{l}0.090 \\
(0.059)\end{array}$ & $\begin{array}{l}0.076 \\
(0.058)\end{array}$ & $\begin{array}{l}0.076^{*} \\
(0.042)\end{array}$ & $\begin{array}{l}0.151 * * * \\
(0.039)\end{array}$ \\
\hline КМOB & $\begin{array}{l}0.001 \\
(0.001)\end{array}$ & $\begin{array}{l}0.001 \\
(0.001)\end{array}$ & $\begin{array}{l}-0.002^{* *} \\
(0.001)\end{array}$ & $\begin{array}{l}-0.005^{* * *} \\
(0.001)\end{array}$ \\
\hline KMOB*Kexp & $\begin{array}{l}-0.006^{* * *} \\
(0.001)\end{array}$ & & $\begin{array}{l}0.000 \\
(0.002)\end{array}$ & \\
\hline KMOB*FDI97 & & $\begin{array}{l}-0.025^{* * * *} \\
(0.007)\end{array}$ & & $\begin{array}{l}0.016 * * \\
(0.007)\end{array}$ \\
\hline LMOB & $\begin{array}{l}1.767 * * * \\
(0.481)\end{array}$ & $\begin{array}{l}1.682 * * * \\
(0.494)\end{array}$ & $\begin{array}{l}-0.304 \\
(0.406)\end{array}$ & $\begin{array}{l}-0.227 \\
(0.389)\end{array}$ \\
\hline L.GOVSPEND & $\begin{array}{l}0.092 * * \\
(0.039)\end{array}$ & $\begin{array}{l}0.082 * * \\
(0.039)\end{array}$ & $\begin{array}{l}0.153 * * * \\
(0.039)\end{array}$ & $\begin{array}{l}0.165 * * * \\
(0.039)\end{array}$ \\
\hline L.GOVDEBT & $\begin{array}{l}0.031 * * * \\
(0.009)\end{array}$ & $\begin{array}{l}0.026 * * * \\
(0.009)\end{array}$ & $\begin{array}{l}0.061 * * * \\
(0.007)\end{array}$ & $\begin{array}{l}0.073 * * * \\
(0.007)\end{array}$ \\
\hline $65+$ & $\begin{array}{l}-0.791 * * * \\
(0.290)\end{array}$ & $\begin{array}{l}-0.884^{* * * *} \\
(0.196)\end{array}$ & $\begin{array}{l}0.172 \\
(0.184)\end{array}$ & $\begin{array}{l}0.0541 \\
(0.135)\end{array}$ \\
\hline $65+* \operatorname{Kexp}$ & $\begin{array}{l}-0.214 \\
(0.214)\end{array}$ & & $\begin{array}{l}0.124 \\
(0.151)\end{array}$ & \\
\hline $65+*$ FDI97 & & $\begin{array}{l}-1.595 \\
(1.096)\end{array}$ & & $\begin{array}{l}2.201 * * \\
(0.904)\end{array}$ \\
\hline Observations & 534 & 534 & 540 & 540 \\
\hline$R$-squared & 0.539 & 0.550 & 0.368 & 0.421 \\
\hline N. of countries & 29 & 29 & 29 & 29 \\
\hline Hansen $\mathbf{J}$ & $2.959 *$ & 2.012 & $3.346^{*}$ & $3.199 *$ \\
\hline K-Paap rk LM & $48.710^{* * *}$ & $47.844 * * *$ & $50.175^{* * *}$ & $49.488 * * *$ \\
\hline K-Paap rk Wald F & 48.239 & 46.621 & 50.146 & 48.696 \\
\hline
\end{tabular}

Dependent variable: EATR (col. (1)-(2)); tax wedge on high wages (col. (3)-(4)). Estimation period: 1997-2017

All columns include country and time fixed effects. LMOB instrumented

Robust standard errors in parentheses. ${ }^{* * *} p<0.01,{ }^{*} * p<0.05, * p<0.1$

\section{Conclusion}

By relaxing the assumptions of perfect capital mobility and perfect labor immobility, we have shown theoretically that financial globalization does not necessarily lead to a race-to-the-bottom of capital tax rates and labor mobility does matter for both capital and labor taxation. More precisely, both our simplified model and the simulations of our complete model show that only a net capital-exporting country 
will feel a sharp downward pressure on its corporate income tax rate and a pressure to shift the tax burden onto labor when capital mobility increases. Net capital exporters are also more sensitive to changes in labor mobility, and their tax rates react more to population ageing.

Our theoretical results are supported by our econometric estimations, run on a panel of 29 OECD countries over the period of 1997-2017. We find evidence that capital mobility has a negative impact on capital taxation and a positive impact on labor taxation, but only for net capital-exporting countries. Conversely, we find that rising labor mobility increases capital taxation with no robust impact on labor taxation. However, the impact of population ageing on capital taxation is greater in magnitude than the impacts of either capital or labor mobility.

Our results suggest that a country that opens itself up to capital inflows may be less vulnerable in its ability to tax capital than a country that exposes itself to capital outflows. But these effects are secondary when compared with population ageing and variations in government spending and debt.

This paper may be extended in various ways. In particular, a game between countries could be studied through reaction functions to study either tax competition or tax cooperation strategies. Additionally, the development of immaterial capital and entrepreneurship has offered new possibilities for tax optimization, with increased pressure on tax rates (Fossen et al., 2020) — a development that also interacts with international goods and factor mobility (Keen \& Konrad, 2013). Finally, the COVID-19 crisis has demonstrated that new technologies offer sizeable opportunities for households to live and work in different locations, which challenges a key assumption of our model. These developments are left for future research.

\section{Appendix A. Derivation of the theoretical model}

In this appendix, we prove the results that are discussed Sect. 2. We proceed in three steps. First, we show how to write the optimization problem. Second, we present some results related to the existence and uniqueness of the solution. Third, we show how do derive the expressions presented Sect. 2.3.

\section{A.1 The optimization problem}

Using the fact that $k:=K /(L+D)$, and equations in (1), the government's optimization problem can be written as: 


$$
\begin{aligned}
& \max _{\tau_{K}, \tau_{L}} U\left(\frac{L}{L+D} y_{L}+\frac{\gamma D}{L+D} y_{D}, \frac{G}{L+D}\right)
\end{aligned}
$$

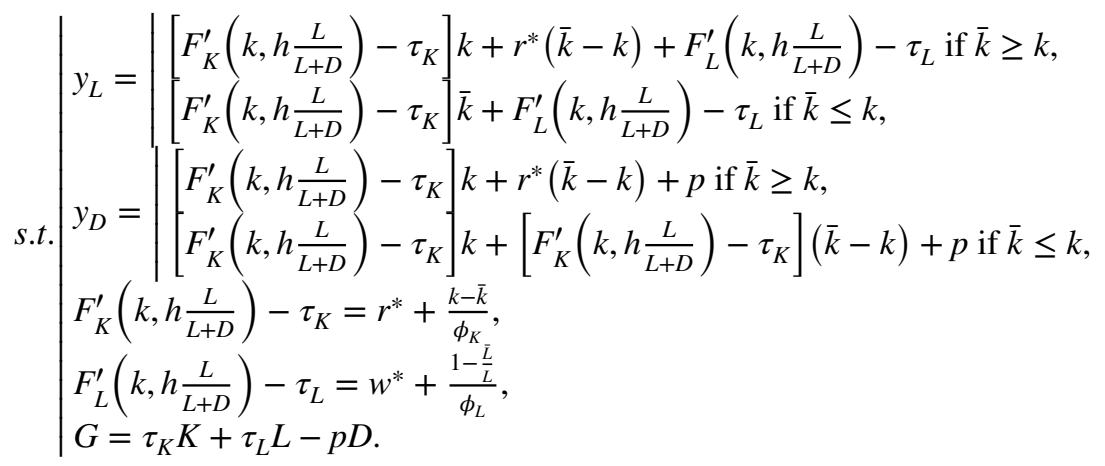

The endogenous variables of this problem are $\tau_{K}, \tau_{L}, L, G, y_{L}, y_{D}, k$, while the exogenous parameters are $D, \gamma, r^{*}, w^{*}, \bar{k}, p, \phi_{K}, \phi_{L}$. The weighted average personal income can then be simplified using (9) and (10). The average spending can be rewritten by replacing the tax rates $\tau_{K}$ and $\tau_{L}$ and rearranging the expression using the homogeneity property of the production function. The problem is then rewritten as an optimization problem in $(k, L)$ :

$$
\begin{aligned}
& \max _{k, L} U\left(\frac{L}{L+D} y_{L}+\frac{\gamma D}{L+D} y_{D}, \frac{G}{L+D}\right) \\
& s . t . \\
& \frac{L}{L+D} y_{L}+\frac{\gamma D}{L+D} y_{D}=\mid \begin{array}{l}
\frac{L+\gamma D}{L+D}\left[\frac{k(k-\bar{k})}{\phi_{K}}+r^{*} \bar{k}\right]+\frac{L}{L+D}\left[w^{*}+\frac{\left(1-\frac{\bar{L}}{L}\right)}{\phi_{L}}\right]+\frac{\gamma D}{L+D} p \text { if } \bar{k} \geq k, \\
\frac{L+\gamma D}{L+D}\left[\frac{\bar{k}(k-\bar{k})}{\phi_{K}}+r^{*} \bar{k}\right]+\frac{L}{L+D}\left[w^{*}+\frac{\left(1-\frac{\bar{L}}{L}\right)}{\phi_{L}}\right]+\frac{\gamma D}{L+D} p \text { if } \bar{k} \leq k, \\
\frac{G}{L+D}=F\left(k, h \frac{L}{L+D}\right)-\left(r^{*}+\frac{(k-\bar{k})}{\phi_{K}}\right) k-\left(w^{*}+\frac{\left(1-\frac{\bar{L}}{L}\right)}{\phi_{L}}\right) \frac{L}{L+D}-p \frac{D}{L+D} .
\end{array}
\end{aligned}
$$

Moreover, the tax rates satisfy:

$$
\begin{aligned}
& \tau_{K}=F_{K}^{\prime}\left(k, h \frac{L}{L+D}\right)-r^{*}-\frac{(k-\bar{k})}{\phi_{K}}, \\
& \tau_{L}=F_{L}^{\prime}\left(k, h \frac{L}{L+D}\right)-w^{*}-\frac{\left(1-\frac{\bar{L}}{L}\right)}{\phi_{L}} .
\end{aligned}
$$

\section{A.2 Existence and uniqueness of the solution}

To reduce the length of the proofs, we assume in this subsection that function $U$ is additively separable and that $D=0$. 
Lemma 1 There exists a unique solution to problem (A.2).

Proof The first-order conditions with respect to $(k, L)$ are:

$$
\begin{aligned}
& U_{Y}^{\prime} \frac{(2 k-\bar{k})}{\phi_{K}}+U_{G}^{\prime}\left[F_{K}^{\prime}(k, h)-r^{*}-\frac{(2 k-\bar{k})}{\phi_{K}}\right]=0 \text { if } \bar{k} \geq k, \\
& U_{Y}^{\prime} \frac{\bar{k}}{\phi_{K}}+U_{G}^{\prime}\left[F_{K}^{\prime}(k, h)-r^{*}-\frac{(2 k-\bar{k})}{\phi_{K}}\right]=0 \text { if } \bar{k} \leq k,
\end{aligned}
$$

and:

$$
U_{Y}^{\prime}-U_{G}^{\prime}=0
$$

where $U_{Y}^{\prime}$ and $U_{G}^{\prime}$ are the first derivatives of function $U$. To ease the reading, we have dropped the expressions in parenthesis. Let us now turn to the second-order conditions. For $\bar{k} \geq k$, the Hessian matrix evaluated at the optimum is written as:

$$
H_{1}=\left[\begin{array}{cc}
U_{Y Y}^{\prime \prime}\left[\frac{(2 k-\bar{k})}{\phi_{K}}\right]^{2}+U_{G G}^{\prime \prime}[\mathcal{X}(k)]^{2}+U_{G}^{\prime} F_{K K}^{\prime \prime}(k, h) & U_{Y Y}^{\prime \prime} \frac{(2 k-\bar{k})}{\phi_{K}}-U_{G G}^{\prime \prime} \mathcal{X}(k) \\
U_{Y Y}^{\prime \prime} \frac{(2 k-\bar{k})}{\phi_{K}}-U_{G G}^{\prime \prime} \mathcal{X}(k) & U_{Y Y}^{\prime \prime}+U_{G G}^{\prime \prime}
\end{array}\right]
$$

where

$$
\mathcal{X}(k):=F_{K}^{\prime}(k, h)-r^{*}-\frac{(2 k-\bar{k})}{\phi_{K}}
$$

The determinant of $H_{1}$ is given by:

$$
D_{H_{1}}=U_{Y Y}^{\prime \prime} U_{G G}^{\prime \prime}\left[F_{K}^{\prime}(k, h)-r^{*}\right]^{2}+\left[U_{Y Y}^{\prime \prime}+U_{G G}^{\prime \prime}\right] U_{G}^{\prime} F_{K K}^{\prime \prime}(k, h)>0 .
$$

For $\bar{k} \leq k$, the Hessian matrix evaluated at the optimum is written as:

$$
H_{2}=\left[\begin{array}{cc}
U_{Y Y}^{\prime \prime}\left[\frac{\bar{k}}{\phi_{K}}\right]^{2}+U_{G G}^{\prime \prime}[\mathcal{X}(k)]^{2}+U_{G}^{\prime}\left[F_{K K}^{\prime \prime}(k, h)-\frac{2}{\phi_{K}}\right] & U_{Y Y}^{\prime \prime} \frac{\bar{k}}{\phi_{K}}-U_{G G}^{\prime \prime} \mathcal{X}(k) \\
U_{Y Y}^{\prime \prime} \frac{\bar{k}}{\phi_{K}}-U_{G G}^{\prime \prime} \mathcal{X}(k) & U_{Y Y}^{\prime \prime}+U_{G G}^{\prime \prime}
\end{array}\right]
$$

while its determinant is:

$$
D_{H_{1}}=U_{G G}^{\prime \prime} U_{Y Y}^{\prime \prime}\left[\mathcal{X}(k)+\frac{\bar{k}}{\phi_{K}}\right]^{2}+\left[U_{Y Y}^{\prime \prime}+U_{G G}^{\prime \prime}\right] U_{G}^{\prime}\left[F_{K K}^{\prime \prime}(k, h)-\frac{2}{\phi_{K}}\right]>0 .
$$

Let $\left(k^{o}, L^{o}\right)$ be the unique solution of problem (A.2 ). In the next Lemma, we characterize it with respect to the exogenous parameter $\bar{k}$. 
Lemma 2 There exists a unique $\hat{k} \in(0,+\infty)$ such that $k^{o}>\bar{k}$ if $\bar{k}<\hat{k}, k^{o}=\bar{k}$ if $\bar{k}=\hat{k}$ and $k^{o}<\bar{k}$ if $\bar{k}>\hat{k}$.

Proof Let $\left(k^{o}, L^{o}\right)$ be the unique solution of problem (A.2), i.e. the solution of system (A.4)-(A.5). By replacing (A.5) in (A.4), we obtain that $k^{o}$ is defined by:

$$
\begin{aligned}
& F_{K}^{\prime}(k, h)-r^{*}=0 \text { if } \bar{k} \geq k, \\
& F_{K}^{\prime}(k, h)-r^{*}-\frac{2(k-\bar{k})}{\phi_{K}}=0 \text { if } \bar{k} \leq k,
\end{aligned}
$$

Let us define the following functions:

$$
\begin{gathered}
A(k):=F_{K}^{\prime}(k, h)-r^{*} \\
B(k ; \bar{k}):=F_{K}^{\prime}(k, h)-r^{*}-\frac{2(k-\bar{k})}{\phi_{K}} .
\end{gathered}
$$

We note that $A(k)$ satisfies $A^{\prime}(k)<0, \lim _{k=0} A(k)=+\infty$ and $\lim _{k=+\infty} A(k)=-r^{*}$, while $B(k, \bar{k})$ satisfies $B_{k}^{\prime}(k, \bar{k})<0, \quad B_{\bar{k}}^{\prime}(k, \bar{k})>0, \quad \lim _{k=0} B(k, \bar{k})=+\infty \quad$ and $\lim _{k=+\infty} B(k, \bar{k})=-\infty$. Moreover, we have:

$$
A(k) \geq B(k, \bar{k}) \Leftrightarrow k \geq \bar{k} .
$$

For a given $\bar{k}$, we now define $\left(k^{A}, k^{B}\right)$ such that $A\left(k^{A}\right)=B\left(k^{B}, \bar{k}\right)=0$. We then consider three cases according to the sign of $k^{A}-\bar{k}$. If $k^{A}<\bar{k}$, inequality (A.11) implies that $k^{B} \in\left(k^{A}, \bar{k}\right)$, which using (A.11) permits to conclude that $k^{o}=k^{A}$. If $k^{A}=\bar{k}$, inequality (A.11) implies that $k^{B}=\bar{k}$, which using ( A.11) permits to conclude that $k^{o}=\bar{k}$. If $k^{A}>\bar{k}$, inequality (A.11) implies that $k^{B} \in\left(\bar{k}, k^{A}\right)$, which using (A.11) permits to conclude that $k^{o}=k^{B}$.

We conclude the proof by observing that $\hat{k}$ is defined by $B(\hat{k}, \hat{k})=0$ and recalling that $B_{\bar{k}}^{\prime}(k, \bar{k})>0$.

Corollary 1 The optimal solution is a continuous function of $\bar{k}$.

Proof Lemma 2 implies that $k^{o}$ is a continuous function of $\bar{k}$. Concerning $L^{o}$, it is defined as the solution of (A.5) and is therefore also a continuous function of $\bar{k}$.

\section{A.3 Optimal tax rates and the effects of capital and labor mobilities}

We now consider the full problem (A.2). The first-order conditions with respect to $(k, L)$ are: 


$$
\begin{aligned}
& U_{Y}^{\prime}\left[\frac{(2 k-\bar{k})}{\phi_{K}} \frac{L+\gamma D}{L+D}\right]+U_{G}^{\prime}\left[F_{K}^{\prime}-r^{*}-\frac{(2 k-\bar{k})}{\phi_{K}}\right]=0 \text { if } \bar{k} \geq k, \\
& U_{Y}^{\prime}\left[\frac{\bar{k}}{\phi_{K}} \frac{L+\gamma D}{L+D}\right]+U_{G}^{\prime}\left[F_{K}^{\prime}-r^{*}-\frac{(2 k-\bar{k})}{\phi_{K}}\right]=0 \text { if } \bar{k} \leq k,
\end{aligned}
$$

and:

$$
\begin{aligned}
& U_{Y}^{\prime}\left[(1-\gamma) D\left(\frac{\bar{k}(k-\bar{k})}{\phi_{K}}+r^{*} \bar{k}+p\right)+D\left(w^{*}+\frac{1}{\phi_{L}}-p\right)+\frac{\bar{L}}{\phi_{L}}\right] \\
& \quad+U_{G}^{\prime}\left[F_{L}^{\prime} D-D\left(w^{*}+\frac{1}{\phi_{L}}-p\right)-\frac{\bar{L}}{\phi_{L}}\right]=0 .
\end{aligned}
$$

One can rewrite (A.15) as follows:

$$
\begin{aligned}
& F_{K}^{\prime}-r^{*}-\frac{(k-\bar{k})}{\phi_{K}}=\frac{1}{\phi_{k}}\left[k-\frac{U_{Y}^{\prime}}{U_{G}^{\prime}} \frac{L+\gamma D}{L+D}(2 k-\bar{k})\right] \text { if } \bar{k} \geq k, \\
& F_{K}^{\prime}-r^{*}-\frac{(k-\bar{k})}{\phi_{K}}=\frac{1}{\phi_{k}}\left[k-\frac{U_{Y}^{\prime}}{U_{G}^{\prime}} \frac{L+\gamma D}{L+D} \bar{k}\right] \text { if } k \geq \bar{k},
\end{aligned}
$$

Using the expression of the optimal tax rate on capital, $\tau_{K}^{o}$, in (A.3), we obtain (13).

One can rewrite (A.16) as follows:

$$
\frac{U_{Y}^{\prime}}{U_{G}^{\prime}}=\frac{\left[D\left(w^{*}+\frac{1}{\phi_{L}}-p\right)+\frac{\bar{L}}{\phi_{L}}-F_{L}^{\prime} D\right]}{\left[D\left(w^{*}+\frac{1}{\phi_{L}}-p\right)+\frac{\bar{L}}{\phi_{L}}-(1-\gamma) D\left(\frac{\bar{k}(k-\bar{k})}{\phi_{K}}+r^{*} \bar{k}+p\right)\right]}
$$

which implies:

$$
\left.\frac{U_{Y}^{\prime}}{U_{G}^{\prime}}\right|_{\gamma=1, D>0}=1-\frac{F_{L}^{\prime} D}{\left[D\left(w^{*}+\frac{1}{\phi_{L}}-p\right)+\frac{\bar{L}}{\phi_{L}}\right]}<1 \text { and }\left.\frac{U_{Y}^{\prime}}{U_{G}^{\prime}}\right|_{D=0}=1 .
$$

Note also that when $D=0$, (A.17) reduces to (A.11). Let us now suppose that the social welfare function is additively separable. Using (A.3), (A.5) can be written as:

$$
U_{Y}^{\prime}\left(\frac{k(k-\bar{k})}{\phi_{K}}+r^{*} \bar{k}+F_{L}^{\prime}(k, h)-\tau_{L}\right)-U_{G}^{\prime}\left(F(k, h)-\left(r^{*}+\frac{(k-\bar{k})}{\phi_{K}}\right) k-F_{L}^{\prime}(k, h)+\tau_{L}\right)=0,
$$

if $\bar{k} \geq k$. Using the homogeneity property of the production function and (A.11), the latter can be rewritten as:

$$
U_{Y}^{\prime}\left(\frac{k(k-\bar{k})}{\phi_{K}}+r^{*} \bar{k}+F_{L}^{\prime}(k, h)-\tau_{L}\right)-U_{G}^{\prime}\left(-\frac{k(k-\bar{k})}{\phi_{K}}+\tau_{L}\right)=0,
$$

which used as an implicit function gives (17). Similarly, (A.5) can be written as: 


$$
U_{Y}^{\prime}\left(\frac{\bar{k}(k-\bar{k})}{\phi_{K}}+r^{*} \bar{k}+F_{L}^{\prime}(k, h)-\tau_{L}\right)-U_{G}^{\prime}\left(\frac{k(k-\bar{k})}{\phi_{K}}+\tau_{L}\right)=0,
$$

if $\bar{k} \leq k$. We obtain

$$
\frac{\partial \tau_{L}}{\partial \phi_{K}}=\frac{-\frac{\bar{k}(k-\bar{k})}{\phi_{K}^{2}} U_{Y Y}^{\prime \prime}+\frac{k(k-\bar{k})}{\phi_{K}^{2}} U_{G G}^{\prime \prime}}{U_{Y Y}^{\prime \prime}+U_{G G}^{\prime \prime}}+\frac{U_{Y Y}^{\prime \prime}\left[\frac{\bar{k}}{\phi_{K}}+F_{K L}^{\prime \prime}(k, h)\right]-U_{G G}^{\prime \prime} \frac{2 k-\bar{k}}{\phi_{K}}}{U_{Y Y}^{\prime \prime}+U_{G G}^{\prime \prime}} \frac{d k}{d \phi_{K}},
$$

where:

$$
\frac{\mathrm{d} k}{\mathrm{~d} \phi_{K}}=\frac{\frac{2 k}{\phi_{K}^{2}}}{F_{K L}^{\prime \prime}(k, h)+\frac{2 k}{\phi_{K}}}>0 .
$$

The sign of $\partial \tau_{L} / \partial \phi_{K}$ if $\bar{k} \leq k$ is therefore ambiguous.

\section{Appendix B. Impact of labor mobility on taxation: the case of a net labor importer}

See Fig. 9.
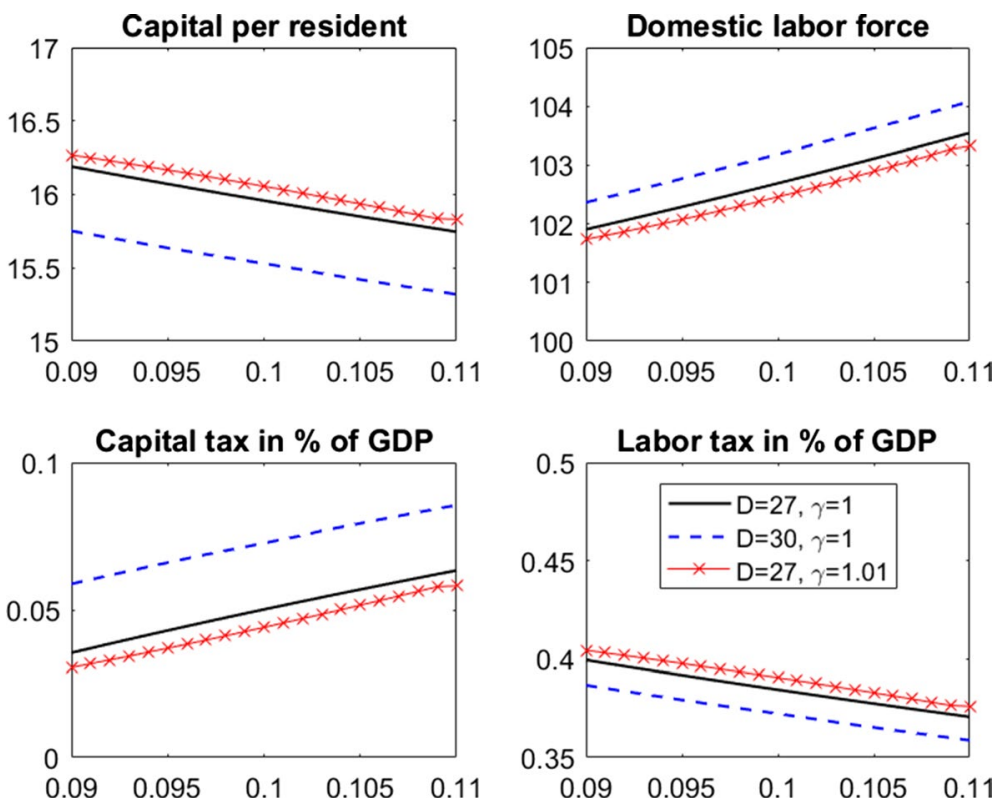

Fig. 9 Impact of labor mobility on taxation: net labor importer $\left(w^{*}=1\right)$ Note: The horizontal axis represents different values of $\phi_{L}$. Source: Model simulations 


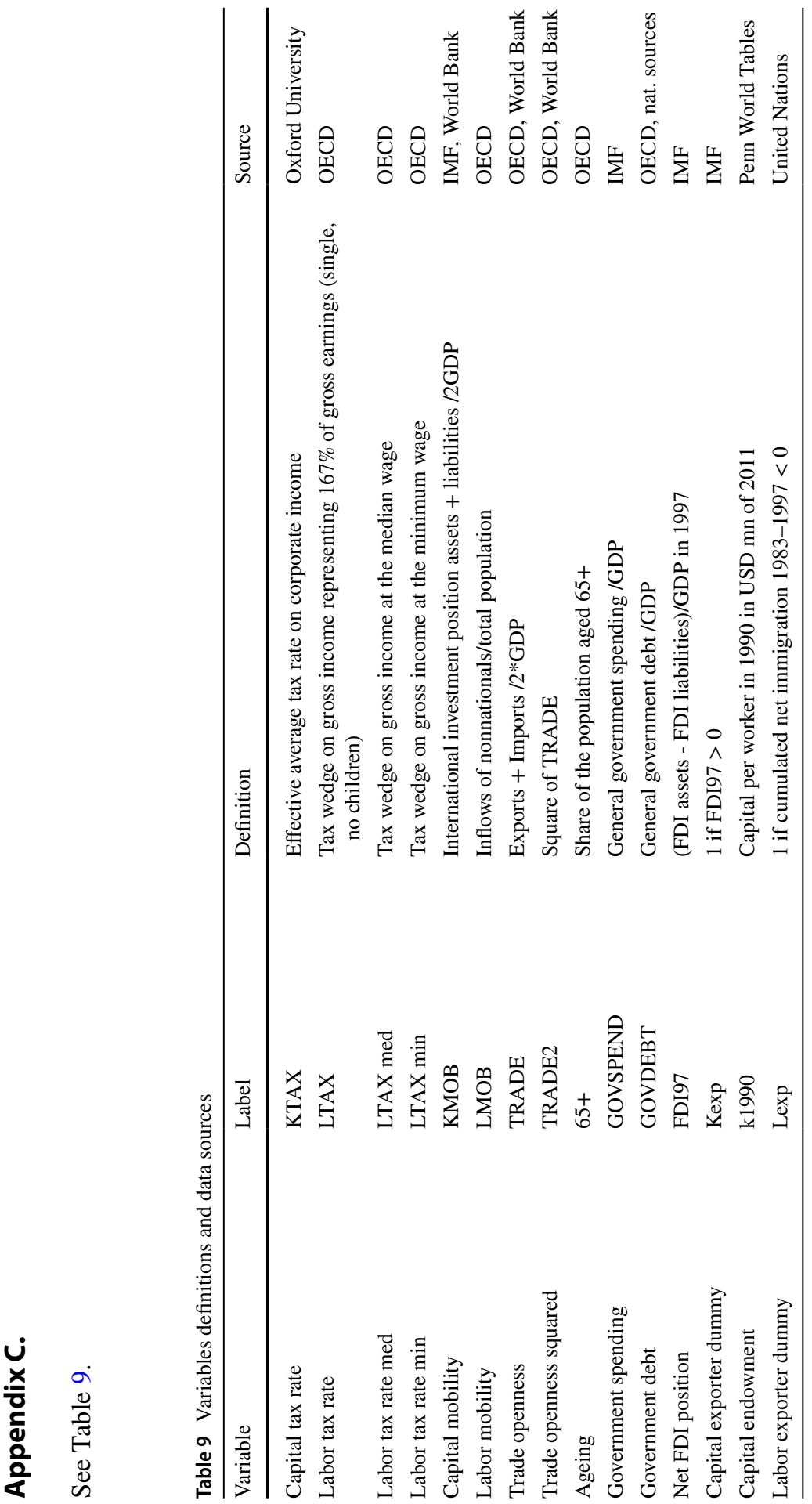




\section{Appendix D. Preliminary estimations}

See Table 10.

Table 10 Preliminary results

\begin{tabular}{|c|c|c|c|c|}
\hline & \multicolumn{2}{|l|}{ KTAX } & \multicolumn{2}{|l|}{ LTAX } \\
\hline & (1) & (2) & (3) & (4) \\
\hline & & IV & & IV \\
\hline \multirow[t]{2}{*}{ TRADE } & -0.231 & $-0.147^{*}$ & -0.160 & $-0.103 * *$ \\
\hline & $(0.189)$ & $(0.081)$ & $(0.120)$ & $(0.050)$ \\
\hline \multirow[t]{2}{*}{ TRADE2 } & $0.236^{*}$ & $0.177 * * *$ & 0.103 & $0.066^{*}$ \\
\hline & $(0.132)$ & $(0.057)$ & $(0.101)$ & $(0.040)$ \\
\hline \multirow[t]{2}{*}{ KMOB } & -0.003 & $-0.002 *$ & -0.002 & $-0.002 * *$ \\
\hline & $(0.003)$ & $(0.001)$ & $(0.002)$ & $(0.001)$ \\
\hline \multirow[t]{2}{*}{ LMOB } & $1.559 * *$ & $1.789 * * *$ & 0.186 & -0.282 \\
\hline & $(0.582)$ & $(0.490)$ & $(0.419)$ & $(0.401)$ \\
\hline \multirow[t]{2}{*}{ L.GOVSPEND } & 0.079 & $0.095^{* *}$ & $0.155^{* *}$ & $0.154 * * *$ \\
\hline & $(0.080)$ & $(0.038)$ & $(0.059)$ & $(0.039)$ \\
\hline \multirow[t]{2}{*}{ L.GOVDEBT } & $0.036^{* *}$ & $0.041 * * *$ & $0.063 * * *$ & $0.059 * * *$ \\
\hline & $(0.017)$ & $(0.008)$ & $(0.016)$ & $(0.007)$ \\
\hline \multirow[t]{2}{*}{$65+$} & $-1.122 * *$ & $-1.139 * * *$ & 0.435 & $0.322 * *$ \\
\hline & $(0.416)$ & $(0.180)$ & $(0.266)$ & $(0.128)$ \\
\hline Observations & 564 & 534 & 572 & 542 \\
\hline$R$-squared & 0.531 & 0.522 & 0.368 & 0.367 \\
\hline Number of countries & 29 & 29 & 29 & 29 \\
\hline Country FE & yes & yes & yes & yes \\
\hline Time FE & yes & yes & yes & yes \\
\hline Hansen J & & 2.042 & & $3.611^{*}$ \\
\hline K-Paap rk LM & & $47.889 * * *$ & & $49.308 * * *$ \\
\hline K-Paap rk Wald F & & 48.046 & & 49.825 \\
\hline
\end{tabular}

Dependent variable: EATR (columns (1)-(2)); tax wedge on high labor income (columns (3)-(4)). Estimation period: 1997-2017

Robust std errors in parentheses. $* * * p<0.01, * * p<0.05, * p<0.1$

Columns (2) and (4): LMOB is instrumented by its first two lags

Acknowledgements We are grateful to the Editor-in-Chief and a referee of this Journal and to Anne Epaulard, Nelly Exbrayat, Guy Gilbert, Friedrich Heinemann, Eckhard Janeba, Sébastien Jean, Etienne Lehmann, Lise Patureau, Hillel Rapoport, Ariell Reshef, Alain Trannoy, Bruno Ventelou, Vincent Vicard, to participants in various seminars and workshops, and to our referees for their useful remarks and criticisms of preliminary drafts. We also thank Amélie Schurich-Rey, Will van der Lande and Tom Verrier for excellent research assistance. The usual disclaimer applies. 


\section{References}

Adam, A., \& Kammas, P. (2007). Tax policies in a globalized world: Is it politics after all? Public Choice, $133,321-341$.

Adam, A., Kammas, P., \& Lagou, A. (2013). The effect of globalization on capital taxation: What have we learned after 20 years of empirical studies? Journal of Macroeconomics, 35, 199-209.

Baldwin, R. (2016). The great convergence, information technology and the new globalization. Harvard University Press.

Baldwin, R., Forslid, R., Martin, P., Ottaviano, G., \& Robert-Nicoud, F. (2003). Economic geography and public policy. Princeton University Press.

Bilicka, K., \& Devereux, M. P. (2012). CBT corporate tax ranking 2012. Saïd Business School.

Borjas, G. T. (1989). Economic theory and international migration. The International Migration Review, 23(3), 457-485.

Braid, R. M. (1996). Tax competition with multiple jurisdictions in each metropolitan area. The American Economic Review, 86(5), 1279-1290.

Bucovetsky, S. (2003). Tax efficient migration and income tax competition. Journal of Public Economic Theory, 5(2), 249-278.

Bucovetsky, S., \& Wilson, J. D. (1991). Tax competition with two tax instruments. Regional Science and Urban Economics, 21(3), 333-350.

Chinn, M. D., \& Ito, H. (2006). What matters for financial development? Capital controls, institutions, and interactions. Journal of Development Economics, 81(1), 163-192.

Clemens, M. A., \& Hunt, J. (2017). The labor market effects of refugees waves: Reconciling conflicting results, NBER working paper 23433.

Devereux, M. P., \& Griffith, R. (1998). Taxes and the location of production: Evidence from a panel of US multinationals. Journal of Public Economics, 68, 35-367.

Dreher, A. (2006). The influence of globalization on taxes and social policy: An empirical analysis for OECD countries. European Journal of Political Economy, 22, 179-201.

Fossen, F. M., Rees, R., Rostam-Afschar, D., \& Steiner, V. (2020). The effects of income taxation on entrepreneurial investment: A puzzle? International Tax and Public Finance, 27, 1321-1363.

French, K., \& Poterba, J. (1991). Investor diversification and international equity markets. American Economic Review, 81(2), 222-26.

Hays, J. C. (2003). Globalization and capital taxation in consensus and majoritarian democracies. World Politics, 56(1), 79-113.

Horioka, C. Y., \& Ford, N. (2017). The solution to the Feldstein-Horioka puzzle. ISER discussion paper 1016, November.

Huddleston, T., Bilgili, O., Joki, A. L., \& Vankova, Z. (2015). Migrant integration policy index. Barcelona Center for International Affairs.

Itskhoki, O., \& Mukhin, D. (2019). Exchange rate disconnect in general equilibrium. Mimeo.

Jordà, O., Knoll, A., Kuvshinov, D., Schularick, M., \& Taylor, A. M. (2019). The rate of return of everything: 1870-2015. The Quarterly Journal of Economics, 134, 1225-1298.

Keen, M., \& Konrad, K. A. (2013). The theory of international tax competition and coordination. Handbook of Public Economics, 5, 257-328.

Kleven, H. J., Landais, C., \& Saez, E. (2013). Taxation and international migration of superstars: Evidence from the European football market. American Economic Review, 103, 1892-1924.

Kleven, H. J., Landais, C., Saez, E., \& Schultz, E. A. (2014). Migration and wage effects of taxing top earners: Evidence from the foreigners' tax scheme in Denmark. Quarterly Journal of Economics, 129, 333-378.

Lee, K. (1997). Tax competition with imperfectly mobile capital. Journal of Urban Economics, 42, $222-242$.

Lehmann, E., Simula, L., \& Trannoy, A. (2014). Tax me if you can! Optimal nonlinear income tax between competing governments. Quarterly Journal of Economics, 129(4), 1995-2030.

Lewis, K. (1999). Trying to explain home bias in equities and consumption. Journal of Economic Literature, 37(2), 571-608.

Liebig, T., Puhani, P. A., \& Sousa-Poza, A. (2007). Taxation and internal migration-Evidence from the Swiss census using community-level variation in income tax rates. Journal of Regional Science, 47 , $807-836$. 
Lindé, J., \& Pescatori, A. (2012). The macroeconomic effects of trade tariffs: Revisiting the Lerner symmetry result. IMF WP/17/151.

Mendoza, E., \& Tesar, L. (2005). Why hasn't tax competition triggered a race to the bottom? Some quantitative lessons from the EU. Journal of Monetary Economics, 52, 164-204.

Nickell, S. J. (1981). Biases in dynamic models with fixed effects. Econometrica, 49, 1417-1426.

Peralta, S., \& van Ypersele, T. (1991). Factor endowments and welfare levels in an asymmetric tax competition game. Journal of Urban Economics, 57, 258-274.

Piketty, T., \& Saez, E. (2012). Optimal labor income taxation. NBER WP No. 18521.

Razin, A., \& Sadka, E. (1991). International tax competition and gains from tax harmonization. Economics Letters, 37(1), 69-76.

Razin, A., \& Sadka, E. (2012). Tax competition and migration: The race-to-the-bottom hypothesis revisited. CESIfo Economic Studies, 58(1), 164-180.

Richter, W., \& Wellisch, D. (1996). The provision of local public goods and factors in the presence of firm and household mobility? Journal of Public Economics, 60, 73-93.

Rodrik, D. (1998). Do more open economies have bigger governments? The Journal of Political Economy, 106, 997-1032.

Roodman, D. (2009). A note on the theme of too many instruments. Oxford Bulletin of Economics and Statistics, 71(1), 135-158.

Slemrod, J. (2004). Are corporate tax rates, or countries, converging? Journal of Public Economics, 88, 1169-1186.

Wildasin, D. (1988). Nash equilibria in models of fiscal competition. Journal of Public Economics, 35, $229-240$.

Wilson, J. D. (1995). Mobile labor, multiple tax instruments, and tax competition. Journal of Urban Economics, 38, 333-356.

Wilson, J. D. (1999). Theories of tax competition. National Tax Journal, 52(2), 269-304.

Zodrow, G., \& Mieszkowski, P. (1986). Pigou, Tiebout, property taxation, and the under provision of local public goods. Journal of Urban Economics, 19, 356-370.

Publisher's Note Springer Nature remains neutral with regard to jurisdictional claims in published maps and institutional affiliations. 